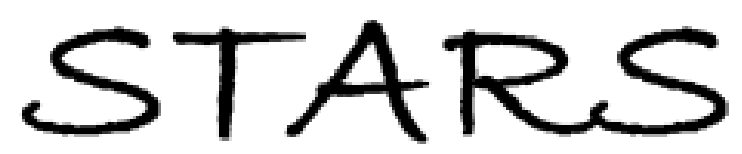

University of Central Florida

STARS

Retrospective Theses and Dissertations

1978

\title{
Zooplankton Abundance and Diversity in Central Florida Grass Carp Ponds
}

Douglas Lee Fry

University of Central Florida, dandjfry@comcast.net

Part of the Biology Commons

Find similar works at: https://stars.library.ucf.edu/rtd

University of Central Florida Libraries http://library.ucf.edu

This Masters Thesis (Open Access) is brought to you for free and open access by STARS. It has been accepted for inclusion in Retrospective Theses and Dissertations by an authorized administrator of STARS. For more information, please contact STARS@ucf.edu.

\section{STARS Citation}

Fry, Douglas Lee, "Zooplankton Abundance and Diversity in Central Florida Grass Carp Ponds" (1978). Retrospective Theses and Dissertations. 287.

https://stars.library.ucf.edu/rtd/287

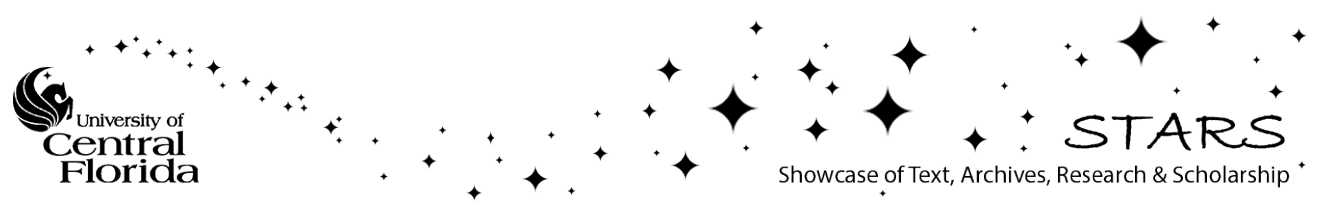


ZOOPLANKTON ABUNDANCE AND DIVERSITY

IN CENTRAL FLORIDA GRASS CARP PONDS

BY

DOUGLAS LEE FRY

B.S., Florida Technological University, 1975

\section{THESIS}

Submitted in partial fulfillment of the requirements for the degree of Master of Science: Biological Science in the Graduate Studies Program of the College of Natural Sciences of Florida Technological University at Orlando, Florida 


\section{ABSTRACT}

The effect of the Asian grass carp (Ctenopharyngodon idella Val.) and aquatic vegetation upon the zooplankton in four adjacent experimental ponds ( 0.139 ha each) was studied for one year. Zooplankton were collected with a newly designed shallow-water sampler. Pond 1 contained no aquatic vegetation. Ponds 2,3 , and 4 contained nine species of rooted aquatic plants. Grass carp were stociked into Pond 2 (65 per ha) and Pond 3 (611 per ha). Physicochemical parameters were similar among the ponds.

Eighty-eight zooplankton species were enumerated. The abundance of zooplankton groups (Rotifera, Cladocera, and Copepoda) was not significantly different among the ponds containing grass carp. No significant differences existed between Pond 3 (high grass carp stocking rate) and Pond 4 (no grass carp) for species diversity ( $\bar{d})$ and species dominance. The number of species and species diversity $(\bar{d})$ was found to be significantly different in Pond 2 (1ow grass carp stocking rate) when compared to Ponds 3 and 4; those differences probably were not due to the grass carp. Grass carp did not appear to affect the water quality of the ponds. In general, it was concluded that grass carp had little, if any, direct or indirect affect upon the zooplankton.

Species commonness was greatest among ponds containing vegetation. Rotifers were the dominant zooplankton group in those ponds. 
Zooplankton were most abundant in the pond without vegetation and were dominated by copepods (notably Tropocyclops prasinus). That pond contained the lowest number of species and had the lowest species diversity $(\bar{d})$ of the ponds. The annual mean for the Simpson Index (species dominance) was highest in Pond 1. The lack of vegetation may have influenced the abundance and diversity of the zooplankton in Pond 1 compared to the other ponds. Those differences also may have been due to selective predation by mosquitofish (Gambusia affinis); that fish was significantly less abundant in Pond 1. 


\section{ACKNOWLEDGEMENTS}

My grateful appreciation is extended to Dr. John A. Osborne for the guidance and opportunities that he provided. I thank $\mathrm{Mr}$. Wayne Boldin, Mr. Jeffrey Spence, Mr. Charles Padera, Mr. Claude Swindel, and Mr. George Taylor for their invaluable assistance. I am grateful to Mr. Ron Kasmaryk, Mr. Stephen Crawford, and Mr. David Pearce for their time and patience instructing me in zooplankton identification. Dr. Carl Prophet graciously assisted with the Cladocera and Copepoda identifications. Many thanks are extended to $\mathrm{Mr}$. Joseph Haibach for his technical expertise and to Mr. Donald Schmitz for his advice and assistance. I thank Drs. I. Jack Stout, Franklin F. Snelson, Jr., and Arthur M. Dutton for their suggestions and their review of the manuscript. Finally, I am indebted to my parents for their patience, guidance, and support. This research was funded by the Florida Department of Natural Resources, Dr. John A. Osborne, Director. 
TABLE OF CONTENTS

Page

List of Tables-1-

List of Figures- vi

Introduction- 1

Materials and Methods-_- 3

Description of Experimental Ponds- 3

Description and Operation of the Zooplankton Sampler

for Shallow Water-_-_- 6

Zooplankton Collections--_- 10

Zooplankton Enumeration--_- 10

Species Diversity-------_-- 11

Physical Measurements--_-_- 11

Chemical Measurements-_-_-_-- 12

Biological Measurements--_- 13

Statistical Analysis-- 13

Results and Discussion-- 15

Faunal Characteristics of the Ponds-_- 15

Species Diversity and Dominance-- 29

Effect of Grass Carp on Zooplankton in Vegetated Ponds------ 33

Effect of Aquatic Vegetation on the Zooplankton--.---.---- 43

Effect of Mosquitofish Populations on the Zooplankton-------- 4?

Sampling Efficiency of the Shallow-Water Zooplankton Sampler- 49

Summary-- 51

Appendix 1- 54

Appendix 2- 59

References Cited-- 61 


\section{IIST OF TABLES}

Table

1. Bathymetric measurements for each of the four FTU experimental ponds

2. Comparison of grass carp growth statistics between initial stocking and renovation in Pond 2 and Pond 3

3. Summary of treatments imposed on four FTU experimental ponds

4. Annual mean abundance of zooplankton species found in four FTU experimental ponds, September, 1975-August, 1976------- 16

5. Annual means of zooplankton groups in four FTU experimental ponds, September, 1975-August, 1976- 20

6. Annual mean zooplankton species diversity values for four FTU experimental ponds, September, 1975-August, 1976------- 30

7. The mean abundance of zooplankton groups in three FTU experimental ponds containing aquatic vegetation during the eight months following the introduction of grass carp in Ponds 2 and 3, December, 1975-August, 1976--

8. Mean values for zooplankton species diversity indices in three FTU experimental ponds containing aquatic vegetation during the eight months following the introduction of grass carp in Ponds 2 and 3, December, 1975-August, 1976

9. Means of physicochemical and biological parameters in Ponds 2,3 , and 4 during the eight months following the introduction of grass carp in Pond 2 and Pond 3, December, 1975-August, 1976

10. Annual means of physicochemical and biological parameters in Ponds 1 and 4, September, 1975-August, 1976-_-

11. The number of Gambusia affinis per trap in four FTU experimental ponds, September, 1975-August, 1976, presented as monthly and annual m 


\section{LIST OF FIGURES}

Fig.

1. Vegetational map showing the placement of plants in Ponds 2,3 , and 4

2. Sketch of 15 liter plexiglass shallow-water zooplankton sampler used to sample four FTU experimental ponds---------

3. The Jaccard Index for species commonness among four FTU experimental ponds, September, 1975-August, 1976----.---

4. Annual percentage of rotifers and microcrustaceans in the total zooplankton abundance in four FTU experimental ponds, September, 1975-August, 1976--

5. Monthly mean zooplankton and $95 \%$ confidence intervals in four FTU experimental ponds, September, 1975-August, 1976---

6. Monthly percentages of rotifers and microcrustaceans in the zooplankton in Pond 1, September, 1975-August, 1976----- 24

7. Monthly percentages of rotifers and microcrustaceans in the zooplankton in Pond 2, September, 1975-August, 1976----- 26

8. Monthly percentages of rotifers and microcrustaceans in the zooplankton in Pond 3, September, 1975-August, 1976-----

9. Monthly percentages of rotifers and microcrustaceans in the zooplankton in Pond 4, September, 1975-August, 1976----- 28

10. Monthly mean number of zooplankton species and $95 \%$ confidence intervals in four FTU experimental ponds, September, 1975-August, 1976

11. Monthly means and $95 \%$ confidence intervals of the Shannon Index $(\vec{d})$ for the zooplankton in four FIU experimental ponds, September, 1975-August, 1976-_-n-.- 32

12. Monthly means and $95 \%$ confidence intervals of the Simpson Index for the zooplankton in four FTU experimental ponds, September, 1975-August, 1976--...- 34 
Fig.

13. Monthly means and $95 \%$ confidence intervals of the Redundancy Index for the zooplankton in four FTU experimental ponds, September, 1975-August, 1976

14. Monthly means and $95 \%$ confidence intervals of the Equitability Index for the zooplankton in four FTU experimental ponds, September, 1975-August, 1976------------ 36 


\section{INTRODUCTION}

The influence of environmental factors upon organisms is often difficult to assess in field studies because of variation in the environment (Borecky, 1956) and differences in sampling methods (Pennak, 1957). Using uniform experimental ponds is one approach to examine relationships between variables in aquatic ecosystems, because the ponds can be controlled (Hall et al., 1970). The use of experimental ponds to study zooplankton ecology is common (see Hasler and Jones, 1949; Armitage and Smith, 1968; Hall et al., 1970; Amoros, 1973; O'Brien and deNoyelles, 1974). In this study, four experimental ponds in central Florida were used to determine the abundance and diversity of zooplankton as affected by vegetation and the Asian grass carp (white amur), Ctenopharyngodon idella (Valenciennes). The shallowness of the ponds necessitated the design of a shallow-water zooplankton sampler.

The difficulties of sampling from shallow waters have limited the number of littoral zooplankton studies. Conventional plankton nets are ineffective in aquatic vegetation since they collect debris, making zooplankton enumeration difficult (Pennak, 1962, 1966; Quade, 1969; Daggett and Davis, 1974). Zooplankton samplers for littoral regions have been developed by Pennak (1962), Andersson et al. (1975), Ackefors (1971), van Heusden (1972), Icanberry and Richardson (1973), and Daggett and Davis (1974). Pennak (1966) determined with the use of a 
sampling tube that zooplankton were less abundant in the littoral region of eleven small Colorado lakes than in the limnetic region. The grass carp is a biological control agent for the submersed plant, Hydrilla verticillata Royle (Kilgen and Smitherman, 1971; Beach et al., 1976; Terrell, 1975, 1976; Cross, 1969). While grass carp fry (less than $30 \mathrm{~mm}$ length) subsist on a diet of zooplankton (Hickling, 1966; Kilgen and Smitherman, 1971; Krupaur, 1967; Opuszynski, 1968; Singh et al., 1969; Stevenson, 1965), the effect of larger grass carp on zooplankton has not been established. It has been suggested that the fecal material of the grass carp may increase the nutrient content of water (Opuszynski, 1972; Stroganov, 1963; Stanley, 1974). The increase in nutrients may promote the growth of phytoplankton, which may indirectly regulate zooplankton abundance and diversity (0'Brien and deNoyelles, 1974; Patalas, 1972; Anderson and Green, 1975; Spodniewsika, 1973; Schindler and Noven, 1971; Hutchinson, 1967). 
MATERIALS AND METHODS

Description of Experimental Ponds

Four adjacent ponds ( 0.139 hectare each) were constructed during June, 1975, on the Florida Technological University campus for the purpose of this study. Bathymetric measurements for the ponds are given in Table 1. The ponds were constructed with a constant four to one slope, with a depth range from 0.0 to $1.5 \mathrm{~m}$. The ponds were filled between June 12-20, 1975. Water level was maintained in each pond throughout the study by weekly filling with 227,124 liters of water (a filling rate of 236.6 liters/min per pond for 16 hours) from a $122 \mathrm{~m}$ well. This was equivalent to a weekly replacement of approximately $18 \%$ of the original pond volume. Nine species of rooted aquatic plants were planted in pure stands in Ponds 2,3 , and 4 prior to filling. The plants included four emergent species (Typha latifolia L., Pontederia lanceolata Nutt., Colocasia esculentum (I.) Schott, and Panicum repens I.), three floating-leaved species (Hydrocotyle umbellata L., Nymphaea odorata Aiton, and Nuphar Iuteum L.), and two submersed species (Vallisneria americana Michx and Egeria densa Planchon). The emergent and floating-leaved plants (seven species) occupied approximately 25\%, eel grass (Vallisneria americana) 25\%, and Brazilian elodea (Eseria densa) $50 \%$ of the surface area of each of those ponds (Fig. 1). New vegetation was permitted to invade Ponds 2,3 , and 4 . Plants were not allowed to grow in Pond 1 during the study. 
Table 1. Bathymetric measurements for each of the four FTU experimental ponds.

\begin{tabular}{|c|c|}
\hline Parameter & Units \\
\hline Maximum depth & $1.82 \mathrm{~m}(6 \mathrm{ft})$ \\
\hline Mean depth & $0.92 \mathrm{~m}(3 \mathrm{ft})$ \\
\hline Surface area & $1,393.55 \mathrm{~m}^{2}\left(15,000 \mathrm{ft}^{2} ; 0.344\right.$ acre; $\left.0.139 \mathrm{ha}\right)$ \\
\hline Shoreline development & 2.856 \\
\hline Volume development & 1.5 \\
\hline Shoreline length & $188.98 \mathrm{~m} \quad(620 \mathrm{ft})$ \\
\hline Volume & $1,274.27 \mathrm{~m}^{3}\left(45,000 \mathrm{ft}^{3} ; 336,620 \mathrm{gal}\right)$ \\
\hline
\end{tabular}


Fig. 1. Vegetational map showing the placement of plants in Ponds 2,3 , and 4 . 


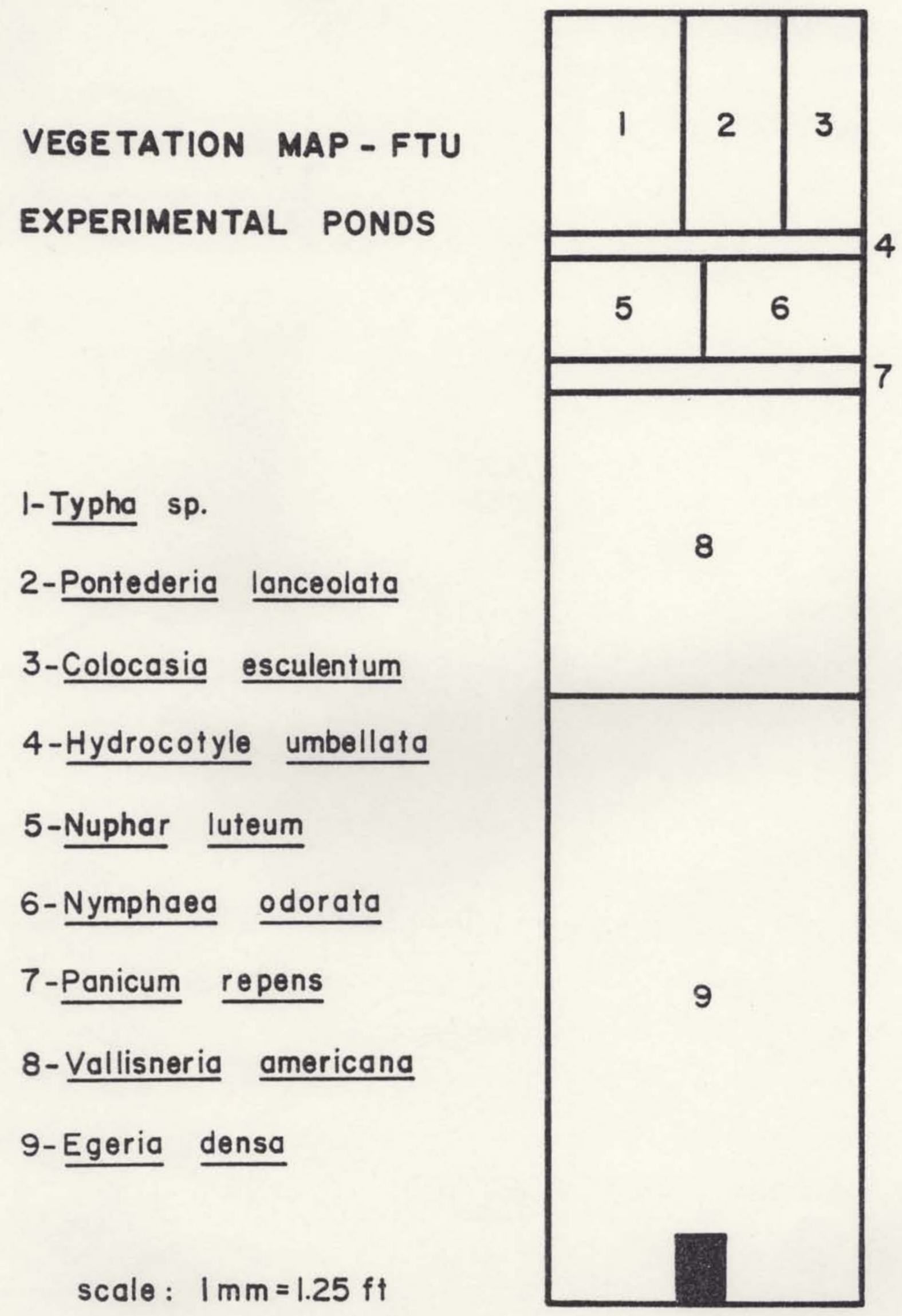


In November, 1975,9 grass carp ( 65 per ha) were stocked in Pond 2, and 85 grass carp ( 611 per ha) were stocked in Pond 3. Weight and length were taken prior to stocking. In December, 1976, the ponds were drained and the weights, lengths, and conditions $\left(\mathrm{K}_{\mathrm{TL}}\right.$ and $\mathrm{K}_{\mathrm{SL}}$ ) of the grass carp were determined (Table 2).

In August, 1975, 85 female mosquitofish, Gambusia affinis (Baird and Girard), were stocked in each of the ponds after this species was discovered in Pond 2. Upon draining the ponds in December, 1976, 125 largemouth bass fingerlings (Micropterus salmoides (Iacepede)) were found in Pond 1. Their mode of introduction and period of existence in the pond is uncertain.

A summary of the fish stocking rates for the ponds is shown in Table 3.

Description and Operation of the Zooplankton Sampler for Shallow Water

A 15 liter zooplankton sampler was constructed from $0.14 \mathrm{~cm}$ clear plexiglass. It was tapered to form a $7.6 \mathrm{~cm}$ opening with a hinged door (Fig. 2). At each station, the sampler was lowered into the water column (at a rate judged slow enough to prevent backwash) until the entire sampler was completely submersed. In very shallow water (i.e., less than $30 \mathrm{~cm}$ ), a horizontal water sample was collected by moving the sampler in an arc within the sampling station. Deeper samples (i.e., $30 \mathrm{~cm}$ to $1.5 \mathrm{~m}$ ) were collected by lowering the sampler into the water at an angle sufficient to sample the entire water column. Care was taken during all sample collections to lower the opening as close to the bottom as possible without collecting debris from the bottom. Samples containing debris were retaken. 
Table 2. Comparison of grass carp growth statistics between initial stocking and renovation in Pond 2 and Pond 3.

November 13, 1975 (Initial Stocking):

\section{Pond 2}

Number

Weight (mean)

Total Length (mean)

$\mathrm{K}_{\mathrm{TL}}{ }^{*}$ (mean)
9

$40 \mathrm{~g}$

$16.5 \mathrm{~cm}$

0.89

\section{Pond 3}

85

$40 \mathrm{~g}$

$16.5 \mathrm{~cm}$

0.89

December 10-15, 1976 (Renovation):

Pond 2

Number

Weight (mean)

Standard Length (mean)

Total Length (mean)

$\mathrm{K}_{\mathrm{SL}}{ }^{* *}$ (mean)

$\mathrm{K}_{\mathrm{TL}}{ }^{*}$ (mean)
6

$1,527.5 \mathrm{~g}$

$40.2 \mathrm{~cm}$

$48.8 \mathrm{~cm}$

2.22

1.23
Pond 3

29

$266.5 \mathrm{~g}$

$21.7 \mathrm{~cm}$

$27.1 \mathrm{~cm}$

2.23

1.12

\footnotetext{
${ }^{*} \mathrm{~K}_{\mathrm{TL}}=\left(\right.$ weight $(\mathrm{g}) /\left(\right.$ length $\left.\left.(\mathrm{cm})^{3}\right)\right) \times 100$, based on total length ${ }^{* *}{ }_{\mathrm{K}}{ }_{\mathrm{SL}}=\left(\right.$ weight $(\mathrm{g}) /\left(\right.$ length $\left.\left.(\mathrm{cm})^{3}\right)\right) \times 100$, based on standard length
} 
Table 3. Summary of treatments imposed on four FTU experimental ponds.

\begin{tabular}{ccccc}
\hline Pond & Aquatic & No. Grass & Small Fishes & Bass \\
Number & Vegetation & Carp & & \\
\hline 1 & Absent & 0 & Present & Present $^{*}$ \\
2 & Present & $9(65 / \mathrm{ha})$ & Present & Absent \\
3 & Present & $85(611 / \mathrm{ha})$ & Present & Absent \\
4 & Present & 0 & Present & Absent \\
\hline
\end{tabular}

* Iargemouth bass (Micropterus salmoides) fingerlings ( $\bar{x}$ total length $=$ $11.4 \mathrm{~cm})$ were present in December, 1976, four months after the termination of the study. The fish accidentally were stocked in the pond, probably during May, 1976. 


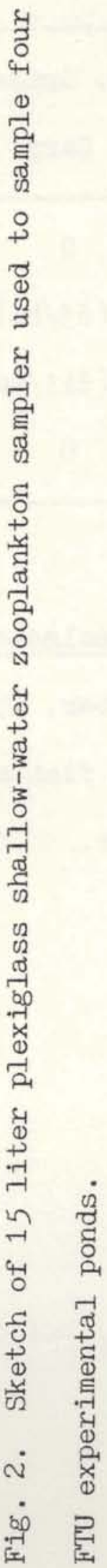




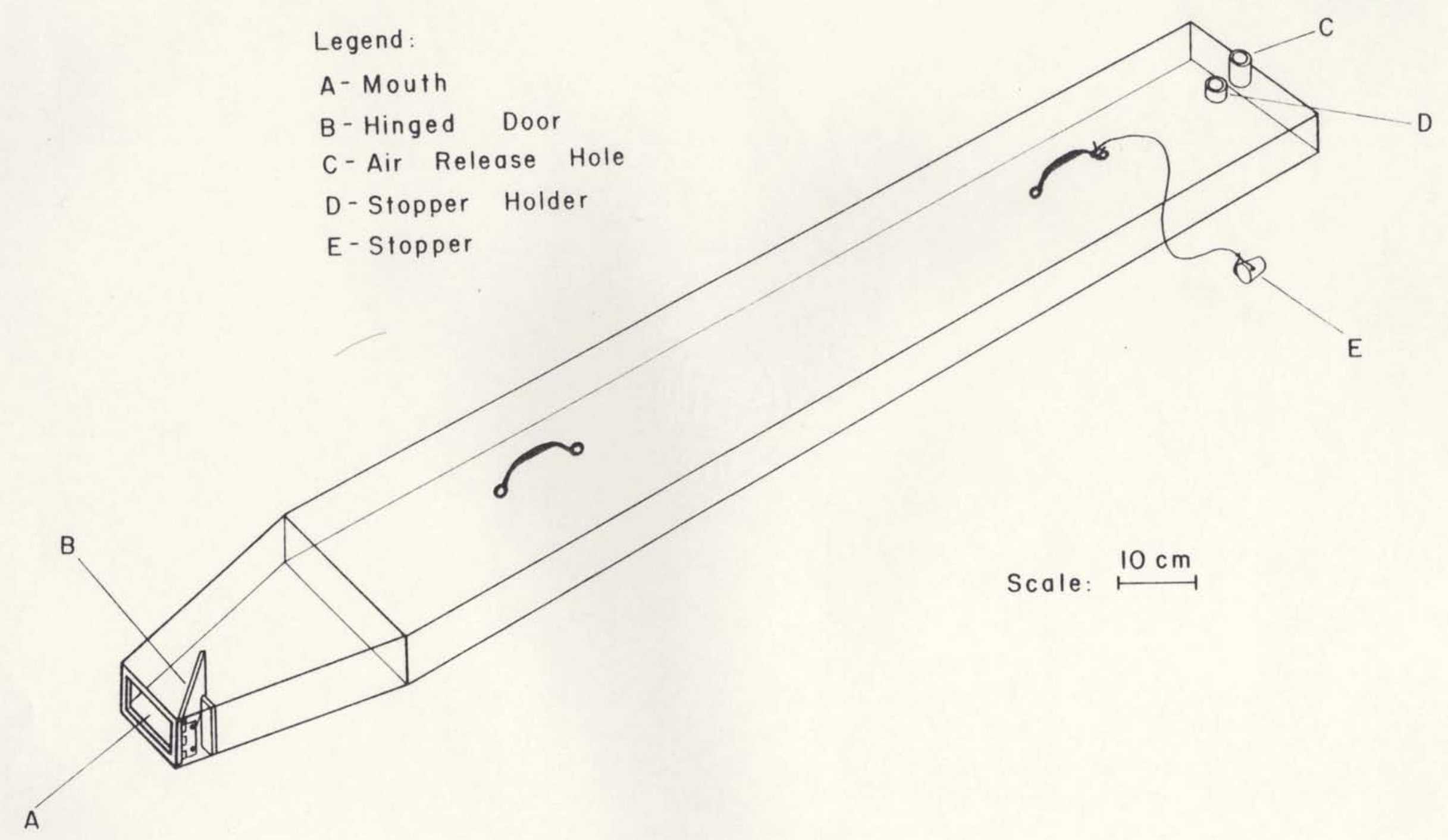


Zooplankton Collections

Zooplankton were collected monthly from three randomly selected stations in each pond between September, 1975, and August, 1976. These stations varied between sampling dates but were the same among ponds on any sampling day. Samples were not collected from Pond 4 in February or from any pond in March. Three samples per station were strained through a no. 20 ( $75 \mu$ mesh size) nylon bolting cloth zooplankton net, composited, and preserved in $3 \%$ formalin. To determine the sampling efficiency of the shallow-water sampler, the sampler was compared to a no. 20 zooplankton net at eleven deep-water stations.

\section{Zooplankton Enumeration}

Samples were concentrated to $100 \mathrm{ml}$ and the number per liter for each species was determined from three, $1 \mathrm{ml}$ subsamples in a SedgwickRafter counting chamber. A Hensen-Stempel automatic pipette was used to obtain the subsamples. Strip counting of the entire chamber was made at a magnification of $100 \mathrm{x}$, although some identifications required a magnification of $200 \mathrm{x}$. A $0.04 \%$ Rose Bengal solution was added to samples prior to counting. Zooplankton were identified using the works of Brooks (1957, 1959), Edmondson (1959), Wilson (1959), Yeatman (1959), Wilson and Yeatman (1959), Pennak (1953), Voigt (1956), Harring and Myers (1922, 1924, 1926, 1928), and Ahlstrom (1934). Contracted rotifers were dissolved in $10 \%$ Clorox in a depression slide to extract the trophi for identification. Zooplankton were enumerated to species and group (Rotifera, Cladocera, Copepoda (Calanoida, Cyclopoida, and Harpactacoida), immature copepods (nauplii and copepodids), and total). Bdelloid rotifers were identified to order 
(Bdelloida) due to the difficulty in their species identification (Edmondson, 1959; Pennak, 1953; Ahlstrom, 1934).

Species Diversity

Species diversity indices were calculated using count data for species and numbers of individuals per species. The indices were:

$$
\overline{\mathrm{d}}=-\Sigma\left(\mathrm{n}_{1} / \mathrm{N}\right) \log _{2}\left(\mathrm{n}_{\mathrm{i}} / \mathrm{N}\right) \quad \text { (Wilhm and Dorris, 1968) }
$$

where: $n_{i}=$ the number of individuals of the ith species

$N=$ the total number of individuals of all species;

$$
\begin{array}{r}
\text { Redundancy }(\mathrm{R})=\left(\overline{\mathrm{d}}_{\max }-\overline{\mathrm{d}}\right) /\left(\overline{\mathrm{d}}_{\max }-\overline{\mathrm{d}}_{\text {min }}\right) \\
\text { (Wilhm and Dorris, 1968) }
\end{array}
$$

where: $\bar{d}_{\max }=$ the maximum $\bar{d}$ value for a given number of species (s)

$\bar{d}_{\text {min }}=$ the minimum $\bar{d}$ value for a given $\mathrm{N}$ and $\mathrm{s}$;

$$
\begin{aligned}
& \text { Equitability }(E)=\bar{d} / \bar{d}_{\max } \quad(P i e l o u, 1966) \\
& \text { Simpson Index }(S I)=\sum\left(n_{i}\left(n_{i}-1\right)\right) /(N(N-1)) \\
& (\text { Simpson, 1949) }
\end{aligned}
$$

where: $n_{i}=$ as given for $\bar{d}$

$$
\mathrm{N}=\text { as given for } \overline{\mathrm{d}}
$$

Jaccard Index (species commonness) $=a /(a+b+c)$

$$
\text { (Jaccard, 1908) }
$$

where: $\mathrm{a}=$ species cooccurring between communities

$$
\begin{aligned}
& \mathrm{b}=\text { species present in only community } 1 \\
& \mathrm{c}=\text { species present in only community } 2
\end{aligned}
$$

Physical Measurements

Water temperature, Secchi disc transparency, and underwater light readings were taken monthly at one fixed deep-water station per pond. 
Water temperature was measured at $0.5 \mathrm{~m}$ depth intervals in the water column with a Yellow Springs Instrument Co. (YSI) telethermometer. Secchi disc transparency was measured with a black and white $20 \mathrm{~cm}$ disc. Relative underwater light readings were taken with a submarine photometer (Kahl Instrument, Model 268WA310) to determine the mean vertical light extinction coefficient (k) for the water column (Hutchinson, 1957). Color and turbidity were taken monthly at two fixed stations per pond and determined spectrophotometrically using the methods from the Environmental Protection Agency (1974) and the American Public Health Association (1971), respectively. Chemical Measurements

Water samples for all chemical analysis, except dissolved oxygen, were collected monthly from two fixed stations per pond with a 1.2 liter Kemmerer water sampler. Specific conductance (micromhos/cm at $25^{\circ} \mathrm{C}$ ) was measured with a YSI Specific Conductivity meter. AIkalinity (total, carbonate, and bicarbonate) and pH were determined with a Sargent-Welch pH meter using Standard Methods (American Public Health Association, 1971). Orthophosphate, nitrite nitrogen, and nitrate nitrogen concentrations were determined from filtered water samples using spectrophotometric techniques (Environmental Protection Agency, 1974; American Public Health Association, 1971). Dissolved oxygen concentrations were measured monthly from the surface and bottom at one fixed deep-water station per pond with a YSI BOD probe and meter; the meter was calibrated with the modified Winkler Method (American Public Health Association, 1971). 
Biological Measurements

Measurements for phytoplankton were determined monthly from one fixed station per pond. Phytoplankton were collected with a 1.2 liter Kemmerer water sampler. Phytoplankton were enumerated to group (filamentous algae, colonial algae, and single-cell algae) with the procedure of Lind (1974). The algal standing crop was estimated monthly with the chlorophyll determination procedure of Richards with Thompson (1952). Periphytic algae production (chlorophylla production $/ \mathrm{m}^{2}$ * day) was estimated monthly using two prewashed $1 \mathrm{~m}$ ( $0.6 \mathrm{~cm}$ diam) nylon ropes suspended at one fixed station per pond from a floating wooden frame. The ropes were replaced monthly to monitor the chlorophyll production with the method of Richards with Thompson (1952).

The mosquitofish relative abundance was determined in each pond from September, 1975, to August, 1976. Samples were obtained with modified minnow traps $(0.635 \mathrm{~cm}$ mesh, covered with nylon window screening affixed to the traps with nylon fishing line and silicone glue). The traps were baited with cat food (958). The traps were submersed below the water surface at four fixed littoral stations for 1 hour ( $\pm 5 \mathrm{~min})$; the trapped fish were counted and returmed. The sampling method was not intended to obtain actual population estimates. Statistical Analysis

Statistical analyses were performed using an IBM 360-370 digital computer with SPSS, SAS, and FTU (Osborne, personal communication) programs. The percent error of the sample mean $(\bar{x})$ to estimate the true mean of the population $(\mu)$ was calculated using the Stein two- 
stage sample (Steel and Torrie, 1960). An unpaired t-test was used to determine mean population differences. Regression of the zooplankton to physical, chemical, and biological parameters was performed using simple linear regression. The significance level for all statistical tests, unless otherwise indicated, was $P<0.05$. 


\section{RESULTS AND DISCUSSION}

\section{Faunal Characteristics of the Ponds}

Eighty-five zooplankton species (65 rotifers, 12 cladocerans, and 8 copepods) were collected from the four ponds (Table 4). Thirteen of these species have not been reported in Florida (Ahlstrom, 1934; Reid and Blake, 1969; Reid and Squibb, 1971; Cowell et al., 1975; Richard, 1973; Nordlie, 1976; Fox et al., 1977). The lowest number of rotifer and copepod species ( 30 and 5, respectively) was found in Pond 1. Rotifer species ranged between 40 and 44 in the ponds containing vegetation. Copepod species ranged between six and eight in those ponds. Cladocerans were represented by seven species in Ponds 1 and 3 , and nine species in Ponds 2 and 4 . Twenty-eight percent of the zooplankton species were common to all ponds. The Jaccard Index for species commonness was highest among ponds containing vegetation (Ponds 2, 3, and 4; Fig. 3). Similar zooplankton species and habitats may have been introduced by the vegetation which was planted in those ponds (Pennak, 1957).

Zooplankton were most abundant in Pond 1, with an annual mean of 212 individuals per liter (Table 5). Their annual means ranged between 107 and 139 individuals per liter in ponds containing vegetation. Rotifers were most abundant and were dominant in the ponds containing vegetation; they comprised between $42.5 \%$ and $79.0 \%$ of the zooplankton. Immature copepods were dominant in Pond 1, comprising $54.2 \%$ of the 
Table 4. Annual mean abundance of zooplankton species found in four FTU experimental ponds, September, 1975-August, 1976. A "T" denotes an annual mean abundance of less than 0.1 individuals per liter.

Individuals per liter

Species

Pond 1 Pond 2 Pond 3 Pond 4

Rotifera

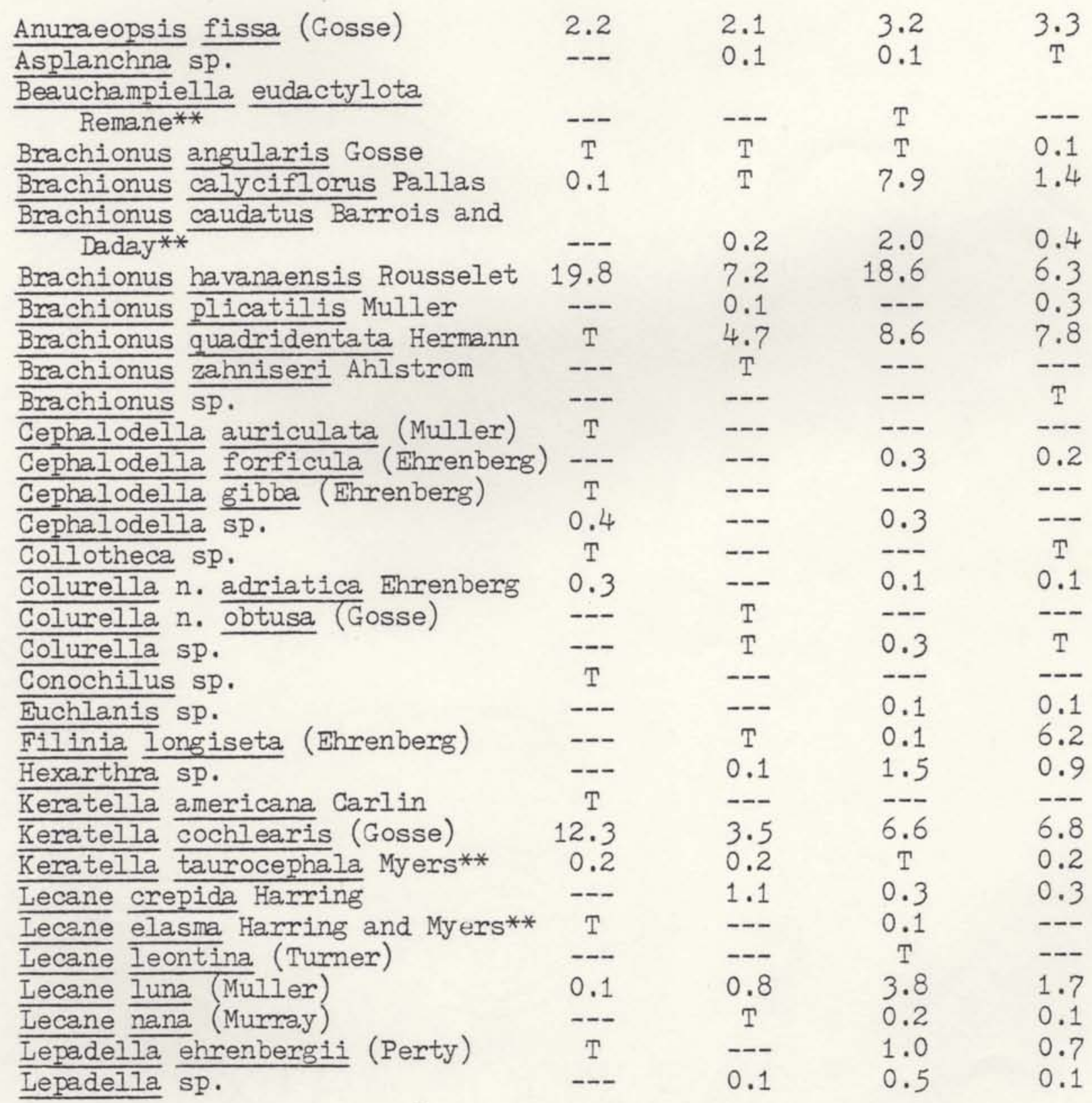


Table 4, continued. Annual mean abundance of zooplankton species.

Pond 1 Pond 2 Pond 3 Pond 4

Lindia sp.

Macrochaetus subquadratus Perty

Monommata sp.

Monostyla bulla Gosse

Monostyla closterocerca Schmarda

Monostyla cornuta (Muller)

Monostyla quadridentata Ehrenberg

Monostyla tethis Haming and

$$
\text { Myers** }
$$

Monostyla sp.

Notommata sp.

Platyias patulus. (Muller)

Polyarthra vulgaris Carlin

Polyarthra sp.

Ptygura melicerta Ehrenberg**

Ptygura sp.

Rousseletia corniculata Harring

Squatinella mutica (Ehrenberg)

Synchaeta $n$. oblonga Ehrenberg

Synchaeta n. Stylata Wierzejsiki

Synchaeta sp.

Trichocerca cylindrica (Imhof)**

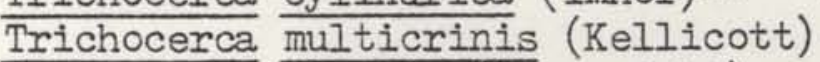

Trichocerca similis (Wierzejski)

Trichocerca weberi (Jennings)**

Trichocerca sp.

Bdelloid Rotifers

Unknown Species 1

1
2
3
4
5
6

(a)

\begin{tabular}{|c|c|c|c|}
\hline--- & 0.1 & 0.3 & $T$ \\
\hline $\mathrm{T}$ & 0.4 & 1.7 & 2.3 \\
\hline-- & --- & $\mathrm{T}$ & --- \\
\hline--- & 0.2 & 1.6 & 4.1 \\
\hline--- & -- & -- & $\mathrm{T}$ \\
\hline--- & $\mathrm{T}$ & 0.3 & 0.7 \\
\hline--- & -- & $\mathrm{T}$ & $\mathrm{T}$ \\
\hline $\mathrm{T}$ & 0.2 & 0.6 & 1.2 \\
\hline--- & --- & --- & $T$ \\
\hline$T$ & 1.3 & 0.2 & 0.3 \\
\hline 0.2 & 0.9 & 0.1 & 0.3 \\
\hline 0.9 & 0.7 & 4.9 & 7.8 \\
\hline-- & 0.2 & 0.3 & -- \\
\hline 0.9 & --- & --- & -- \\
\hline-- & 0.1 & -- & --- \\
\hline 0.2 & $\mathrm{~T}$ & --- & --- \\
\hline--- & -- & --- & $T$ \\
\hline--- & -- & 0.3 & 0.1 \\
\hline-- & -- & 0.1 & 0.6 \\
\hline 0.5 & 0.1 & 0.3 & 0.8 \\
\hline-- & $T$ & -- & --- \\
\hline--- & 0.1 & $\mathrm{~T}$ & 0.3 \\
\hline-- & -- & 3.8 & 16.5 \\
\hline--- & --- & --- & 0.8 \\
\hline 0.2 & 0.3 & 1.7 & 4.8 \\
\hline 3.0 & 20.0 & 3.0 & 31.9 \\
\hline 0.2 & 0.3 & 2.1 & 0.6 \\
\hline-- & $T$ & -- & --- \\
\hline--- & $T$ & --- & --- \\
\hline-- & $\mathrm{T}$ & -- & -- \\
\hline 0.2 & 0.2 & 0.3 & -- \\
\hline 0.3 & --- & --- & -- \\
\hline
\end{tabular}

Cladocera

Alona rectangula Sars

Alona sp.

Bosmina sp.

Ceriodaphnia sp.

Chydorus sphaericus (Muller)

Ilyocriptus spinifer Herrick

Leydiga quadrangularis (Leydig)**

Macrothrix laticornis (Jurine)

0.6

$\mathrm{T}$

T

$---$

0.3

0.1

4.?

$\mathrm{T}$

2.5

3.7

$--$

T

$\mathrm{T}$

$---$

$---$

T

6.1

0.8

$---$

0.3

1.1

0.2

$---$

$---$

0.9

0.1

0.7

0.8

1.6

$---$

1.4

Polyphemus pedicularis (Linne)** -.-

-- 
Table 4, continued. Annual mean abundance of zooplankton species.

\begin{tabular}{cccc} 
Pond 1 & Pond 2 & Pond 3 & Pond 4 \\
\hline--- & 0.1 & --- & $T$ \\
$T$ & $T$ & -- & 0.1 \\
---1 & 0.6 & 0.2 & $T$ \\
0.1 & 0.5 & 0.4 & 0.3
\end{tabular}

Copepoda

Canthocampus sp.

Cyclops varicans rubellus

Lill jeborg

Diaptomus floridanus Marsh

Eucyclops agilis (Koch)

Eucyclops macrurus (Sars)**

0.5

0.3

Eucyclops speratus (Lill jeborg)

Mesocyclops edax (Forbes)

$---$

$1 \cdot 3$

0.1

0.1

Tropocyclops prasinus (Fischer)

$-T$
0.1
$T$
-8.8
44.0

$--$

T

0.8

0.3

$\mathrm{T}$

0.6

$---$

0.1

0.1

T

T

0.1

0.4

$---$

T

1.1

0.1

0.1

8.3

11.9

$\mathrm{T}$

T

2.7

**Species not previously reported from Florida (see text) 
Fig. 3. The Jaccard Index for species commonness among four FTU experimental ponds, September, 1975-August, 1976. 


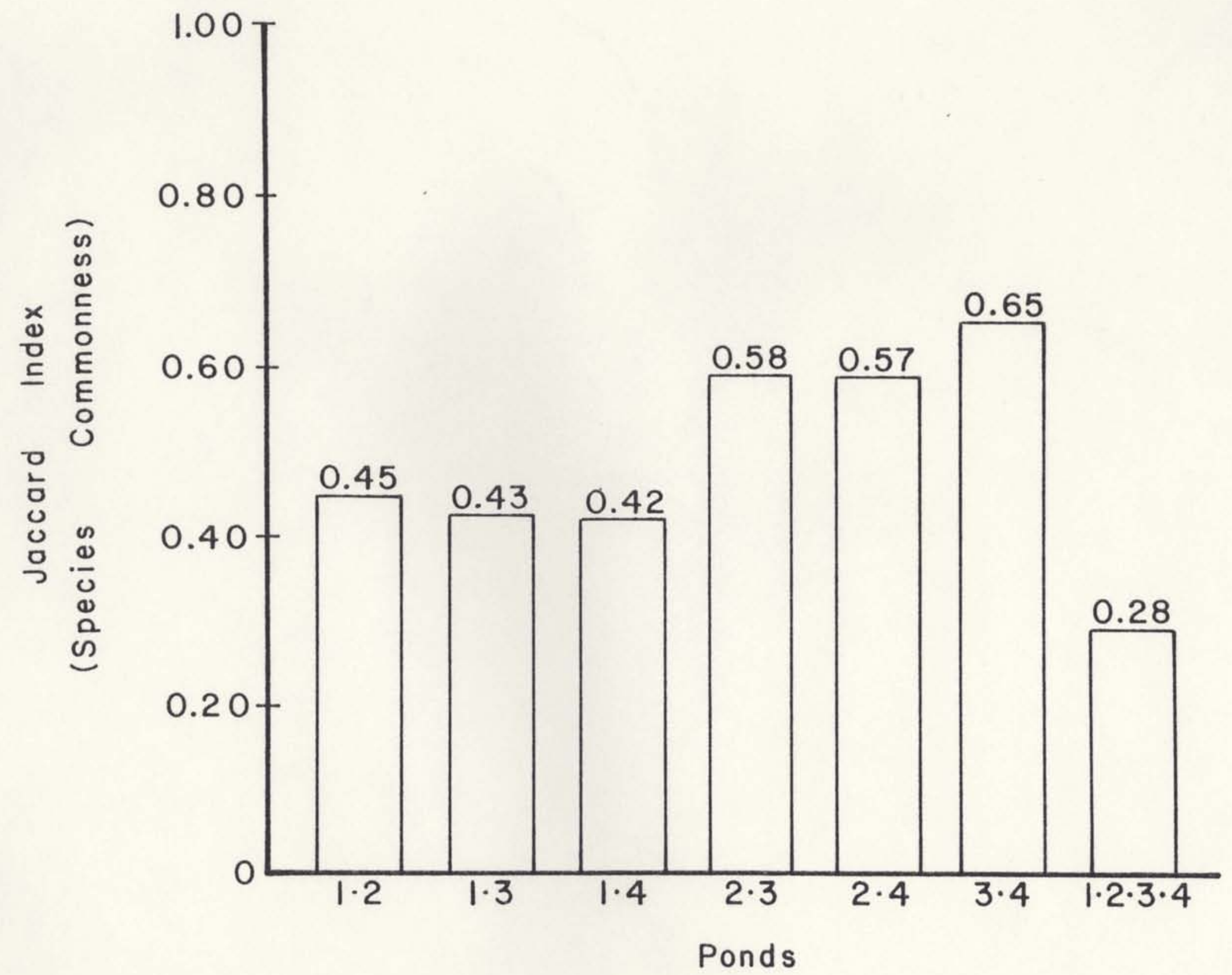


Table 5. Annual means of zooplankton groups in four FTU experimental ponds, September, 1975-August, 1976.

\begin{tabular}{lcccc}
\hline & \multicolumn{4}{c}{ Individuals per liter } \\
\cline { 2 - 5 } Zooplankton Group & Pond 1 & Pond 2 & Pond 3 & Pond 4 \\
\hline Total Zooplankton & 212.1 & 107.1 & 135.6 & 139.2 \\
Rotifera & 42.3 & 45.5 & 77.1 & 110.1 \\
Cladocera & 2.0 & 13.2 & 6.6 & 6.5 \\
Adult Copepoda & 52.9 & 11.3 & 13.1 & 3.7 \\
Cyclopoida & 52.9 & 10.0 & 13.0 & 3.5 \\
Calanoida & $T *$ & $T$ & -1 & 0.1 \\
Harpactacoida &.--- & 1.3 & 0.1 & 0.1 \\
Immature Copepoda & 114.9 & 37.1 & 38.8 & 18.9 \\
\hline
\end{tabular}

*Annual mean abundance of less than 0.1 individuals per liter 
zooplankton (Fig. 4). Adult and immature copepods were three times more abundant in Pond 1 as compared to Ponds 2, 3, and 4. Cyclopoids were the predominant copepod in all ponds. Cladocerans were most abundant (13 individuals per liter) in Pond 2.

The monthly abundances of zooplankton in the ponds are presented in Fig. 5. The abundances of rotifers, cladocerans, adult copepods, and immature copepods per month are presented in Appendix 1 . The abundance of zooplankton was asynchronous among the ponds. Asynchronous population cycles in adjacent experimental ponds are common due to the temporal instability of the physical, chemical, and biological parameters affecting the zooplankton (Hall et al., 1970). Zooplankton in Pond 1 were least abundant during fall, 1975, and most abundant during spring and summer, 1976. Their highest abundance occurred in August ( 463 individuals per liter). Adult and immature copepods made up $90 \%$ of the zooplankton during the warm months (including $98.8 \%$ in July and $98.1 \%$ in August; Fig. 6). Rotifers comprised $53.6 \%$ of the zooplankton in winter and early spring. Cladocera were represented by less than 10 individuals per liter throughout the study.

Zooplankton were least abundant during the fall in Ponds 2, 3, and 4. They were most abundant during winter and early spring in Ponds 2 and 4 (maximum abundances of 316 and 279 individuals per liter, respectively) and during summer in Pond 3 (maximum abundances of 235 individuals per liter in June and 259 individuals per liter in July). Rotifer numbers paralleled those of all zooplankters throughout much of the study in ponds with vegetation. Rotifers composed more than 
Fig. 4. Annual percentage of rotifers and microcrustaceans in the total zooplankton abundance in four FTU experimental ponds, September, 1975-August, 1976. 


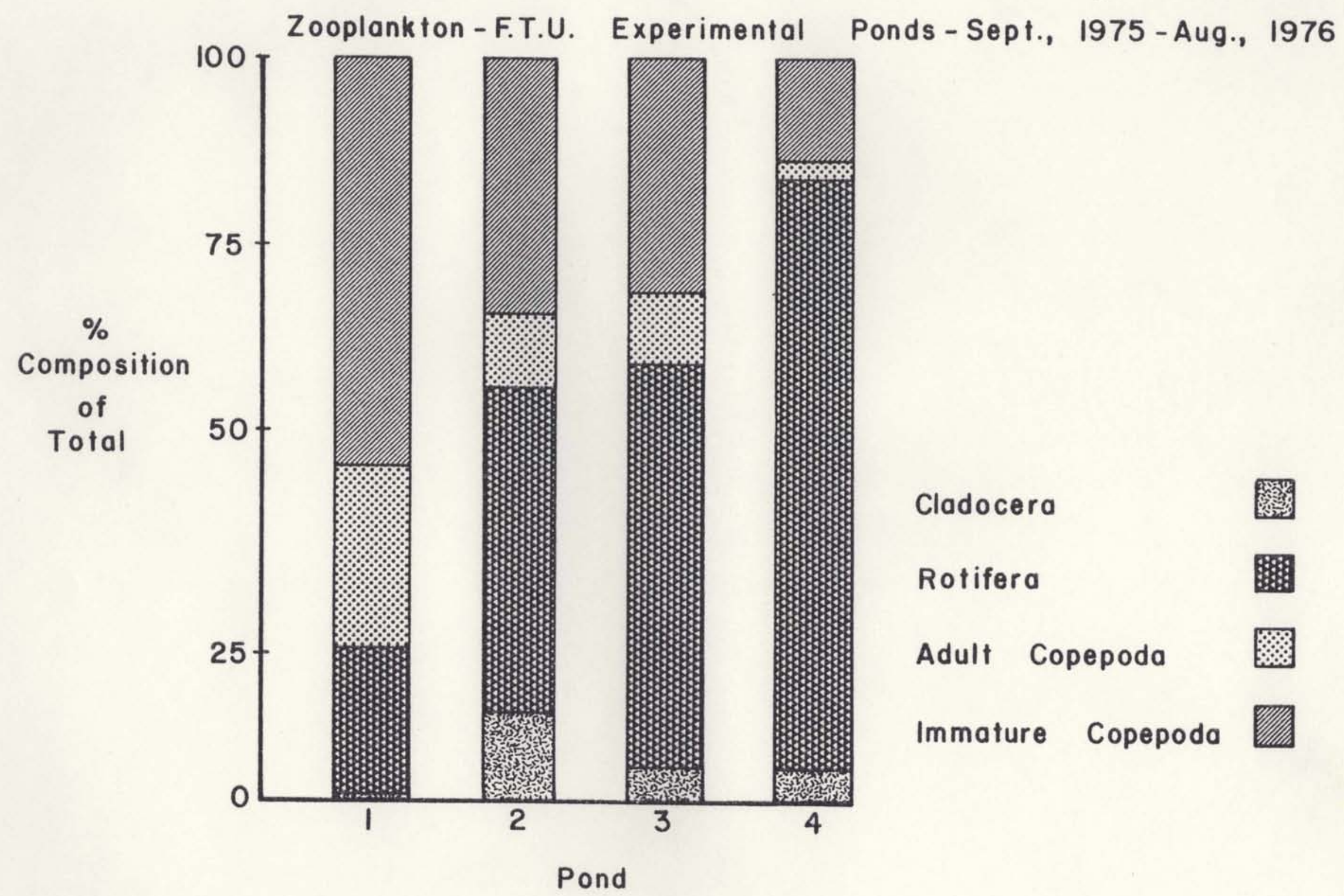


Fig. 5. Monthly mean zooplankton and $95 \%$ confidence intervals in four FTU experimental ponds, September, 1975-August, 1976. 

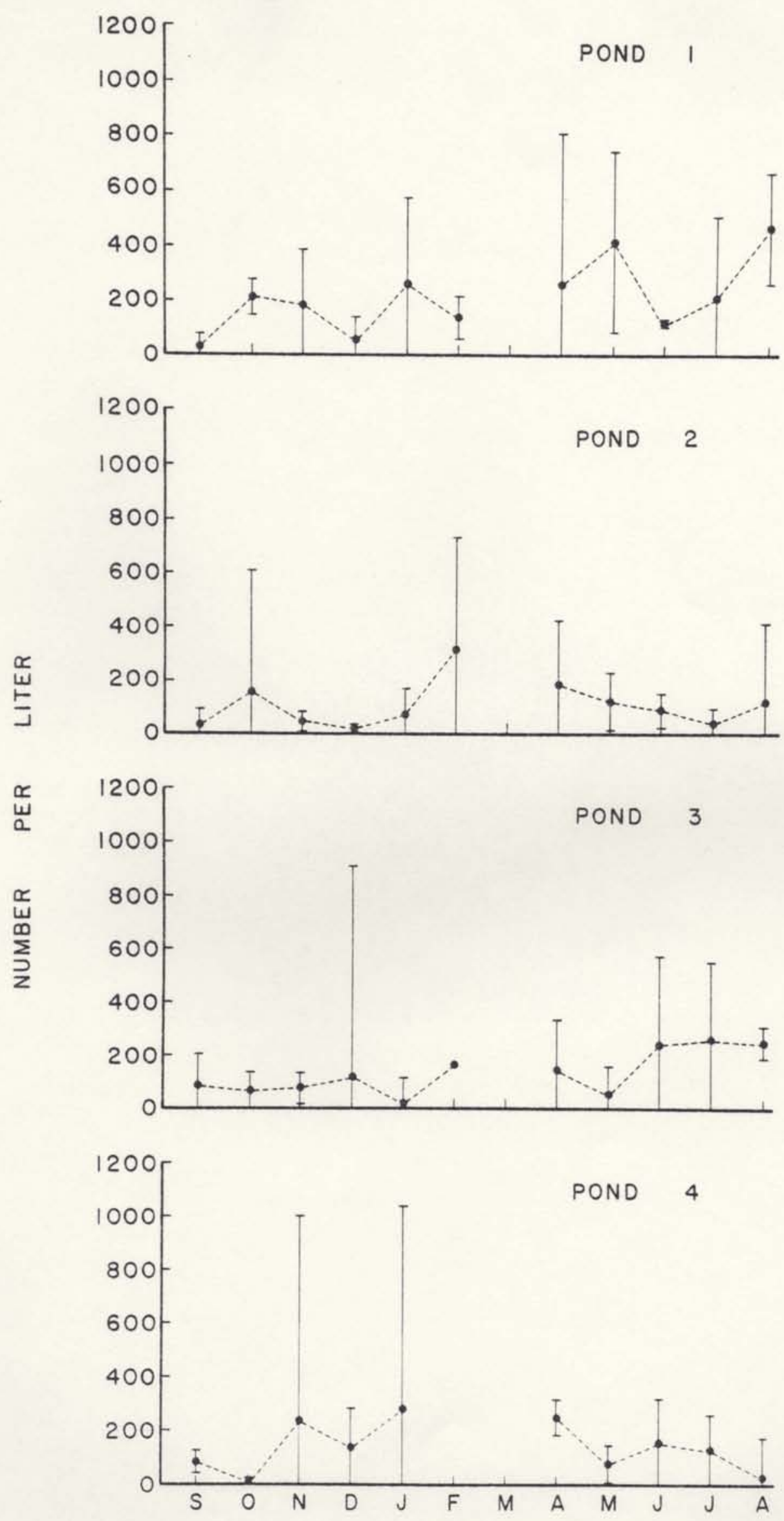

MONTH 
Fig. 6. Monthly percentages of rotifers and microcrustaceans in the zooplankton in Pond 1, September, 1975-August, 1976. 


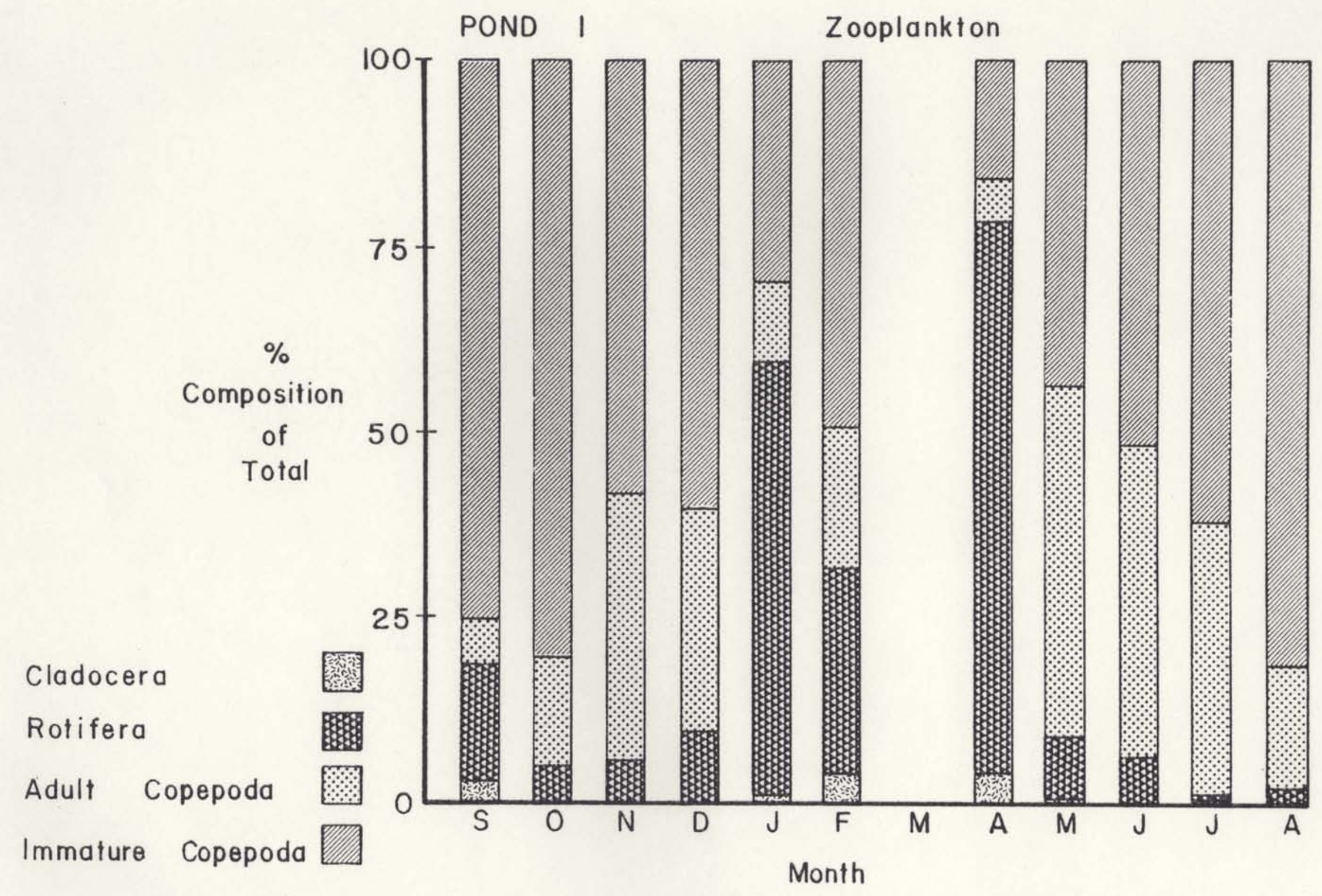


$41 \%$ of the zooplankton in Pond 2 prior to April. Between May and August, however, rotifers composed $17.7 \%$ and copepods (adults and immatures) composed $81.9 \%$ of the zooplankton in that pond (Fig. 7). Rotifers typically made up more than $50 \%$ of the zooplankton in Pond 3 (Fig. 8), and more than $60 \%$ in Pond 4 (Fig. 9). The abundance of copepods was low in Pond 3 prior to May, but increased between June and August. Immature copepods had less than 25 individuals per liter, and adult copepods less than 13 individuals per liter throughout most of the study in Pond 4. Cladocerans were most abundant during fall and early winter in the ponds with vegetation.

Tropocyclops prasinus and Mesocyclops edax were the dominant species in Pond 1, except during January, February, and April when Keratella cochlearis and Brachionus havanaensis were dominant. Prior to May, the most abundant species in Pond 2 were Brachionus quadridentata, Brachionus havanaensis, bdelloid rotifers, and Chydorus sphaericus. Tropocyclops prasinus was dominant between May and August. The most abundant species in Pond 3 were Keratella cochlearis, Brachionus quadridentata, Brachionus calyciflorus, and Brachionus havanaensis. Tropocyclops prasinus was the second most abundant species in May and July, and the dominant species in August. Keratella cochlearis, Brachionus quadridentata, Polyarthra vulgaris, bdelloid rotifers, and Trichocerca similis were the most abundant species in Pond 4. The most abundant rotifer and cladoceran species fluctuated monthly in all ponds. In general, Tropocyclops prasinus was the dominant copepod species in all ponds throughout the study. 
Fig. 7. Monthly percentages of rotifers and microcrustaceans in the zooplankton in Pond 2 , September, 1975-August, 1976. 


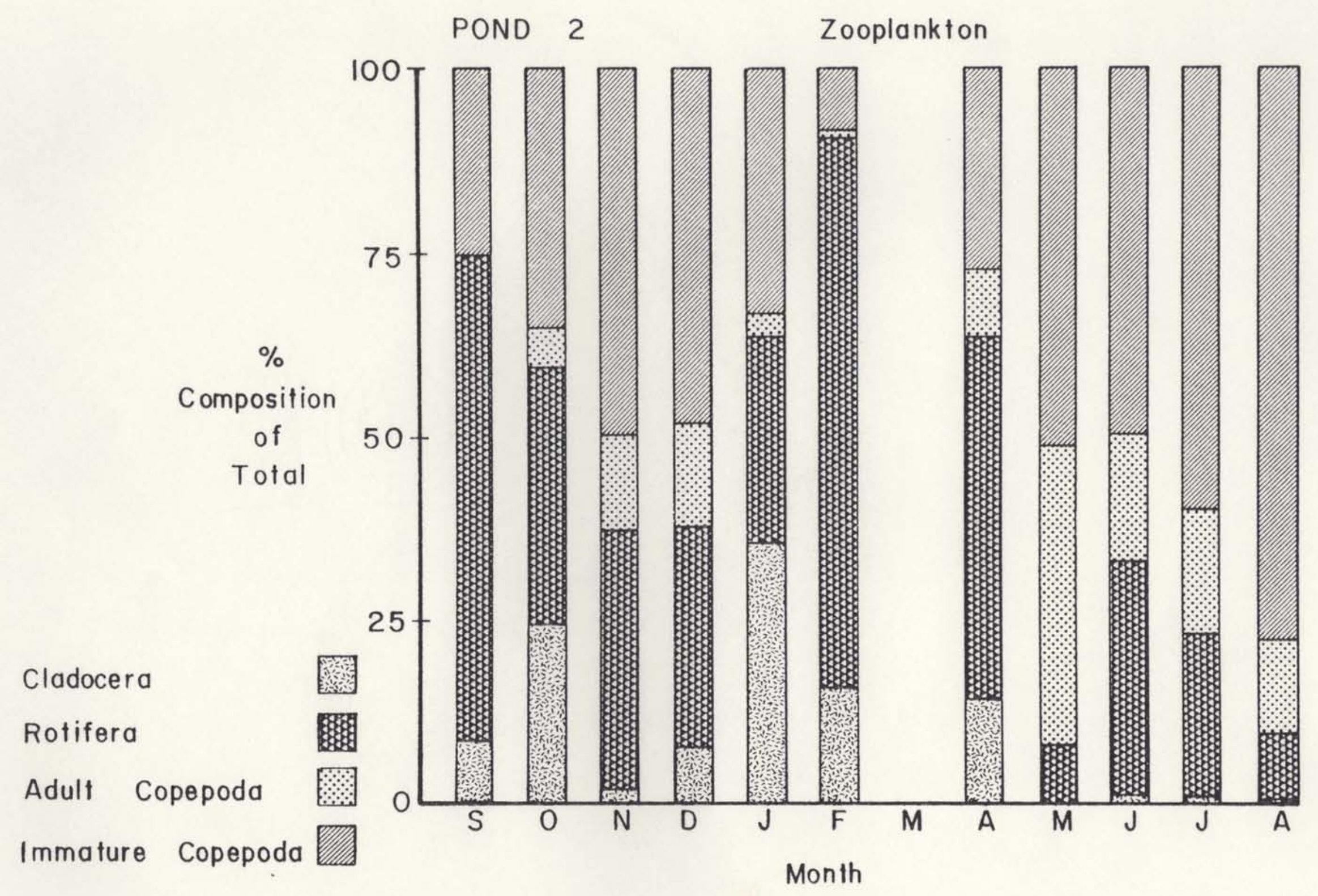


Fig. 8. Monthly percentages of rotifers and microcrustaceans in the zooplankton in Pond 3 , September, 1975-August, 1976. 


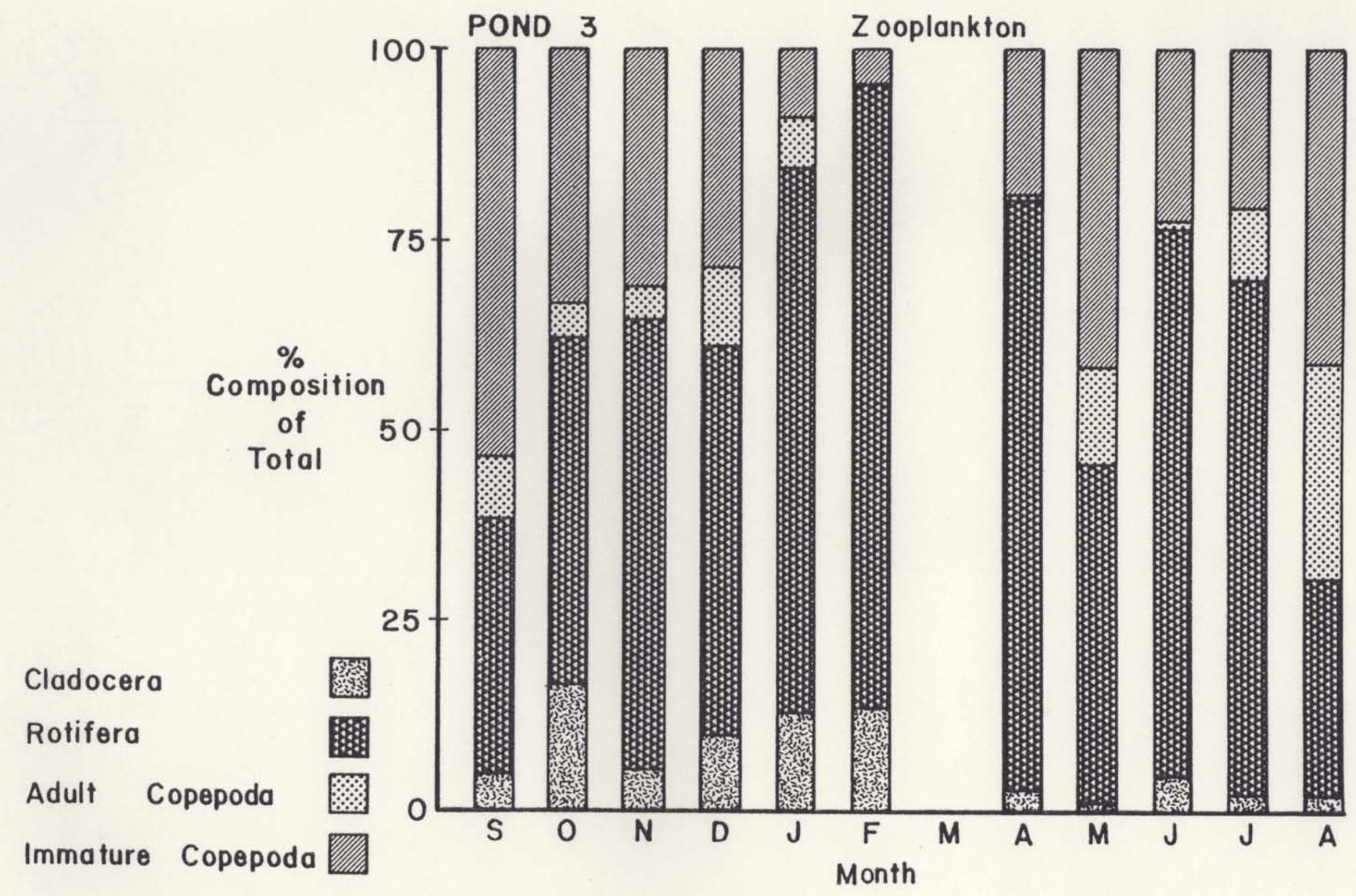


Fig. 9. Monthly percentages of rotifers and microcrustaceans in the zooplankton in Pond 4 , September, 1975-August, 1976. 


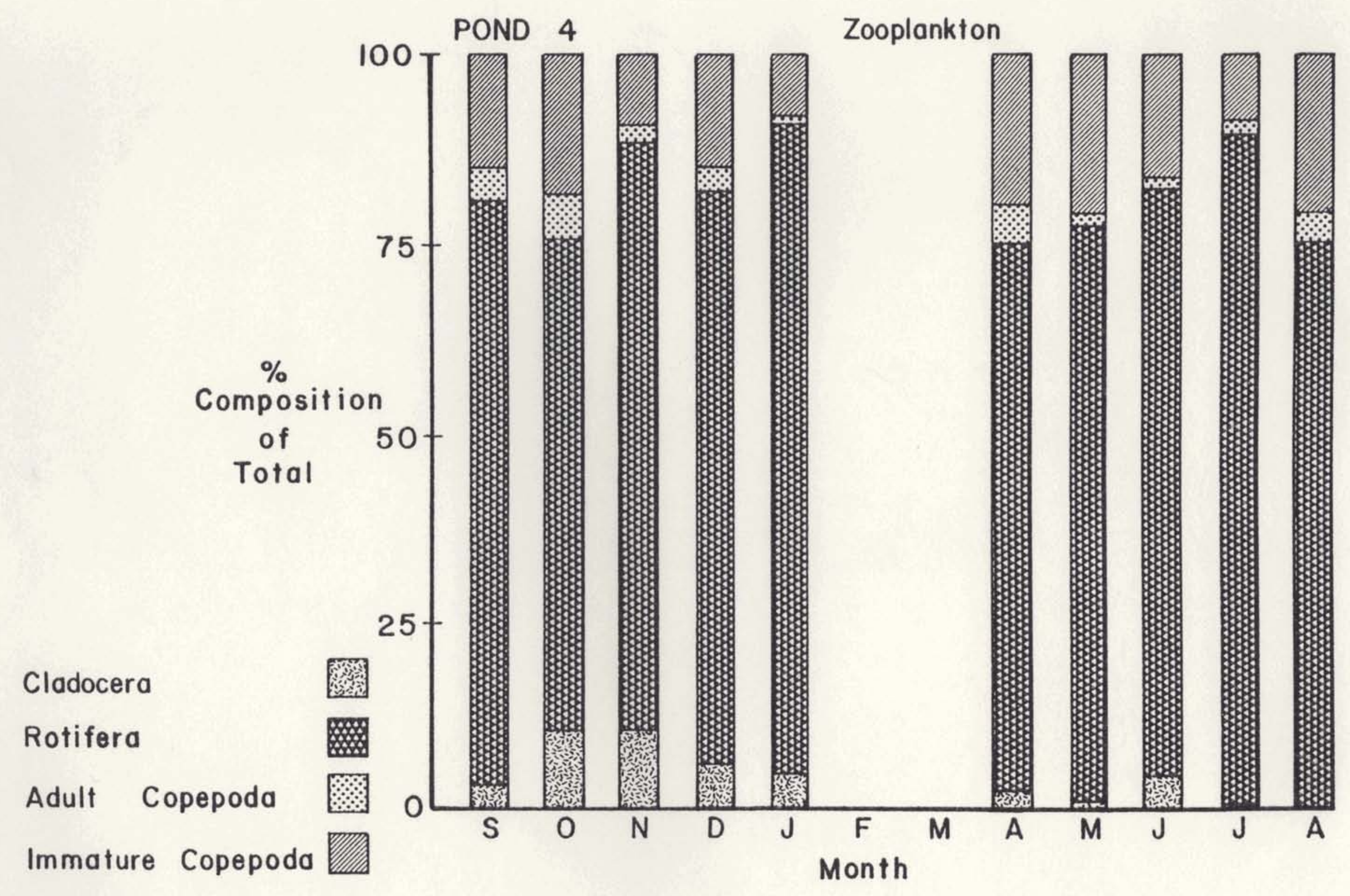


Species Diversity and Dominance

The annual mean number of species ranged from 6 in Pond 1 to 14 in Pond 4 ( $\mathrm{Table} 6)$. The number of species was highest during winter and early spring in Pond 1, during fall in Pond 2, and during summer in Ponds 3 and 4 (Fig. 10). Most of the species were rotifers rather than microcrustaceans; their numbers were mainly responsible for the seasonal variations of species numbers (Appendix 2).

The annual mean species diversity $(\bar{d})$ was 1.34 in Pond $1,2.16$ in Pond 2, and more than 2.5 in Ponds 3 and 4 (Table 6). The values in Pond 1 ranged from 0.77 to 2.13. Species diversity in that pond appeared to be highest during mid-winter when rotifers were most abundant, and lowest between April and August (ranging between 0.94 and 1.30; Fig. 11). During the latter period, Tropocyclops prasinus and Mesocyclops edax comprised between $84.2 \%$ and $96.4 \%$ of the zooplankton. The lack of aquatic vegetation in Pond 1 probably reduced the number of habitats for the zooplankton and may have caused species diversity to be low. The species diversity values remained relatively consistent throughout the study in ponds with vegetation. They were usually lowest in winter when species were low and a dominant rotifer comprised more than $36 \%$ of the zooplankton.

Annual mean Simpson Index values were highest $(0.53)$ in the pond lacking vegetation and lowest in the ponds containing vegetation (ranging between 0.24 in Pond 3 and 0.35 in Pond 2; Table 6). The high value for the Simpson Index in Pond 1 may have been due to the dominance of Tropocyclops prasinus and Mesocyclops edax. Values for this index were lowest (less than 0.5 ) in that pond during winter when 
Table 6. Annual mean zooplankton species diversity values for four FTU experimental ponds, September, 1975-August, 1976.

\begin{tabular}{|c|c|c|c|c|}
\hline Index & Pond 1 & Pond 2 & Pond 3 & Pond 4 \\
\hline Number of Species & 6 & 9 & 12 & 14 \\
\hline Shannon Index $(\overline{\mathrm{d}})$ & 1.34 & 2.16 & 2.68 & 2.51 \\
\hline Simpson Index (SI) & 0.53 & 0.35 & 0.24 & 0.32 \\
\hline Redundancy $(R)$ & 0.42 & 0.29 & 0.22 & 0.25 \\
\hline Equitability (E) & 0.58 & 0.71 & 0.78 & 0.66 \\
\hline
\end{tabular}


Fig. 10. Monthly mean number of zooplankton species and $95 \%$ confidence intervals in four FTU experimental ponds, September, 1975-August, 1976. 

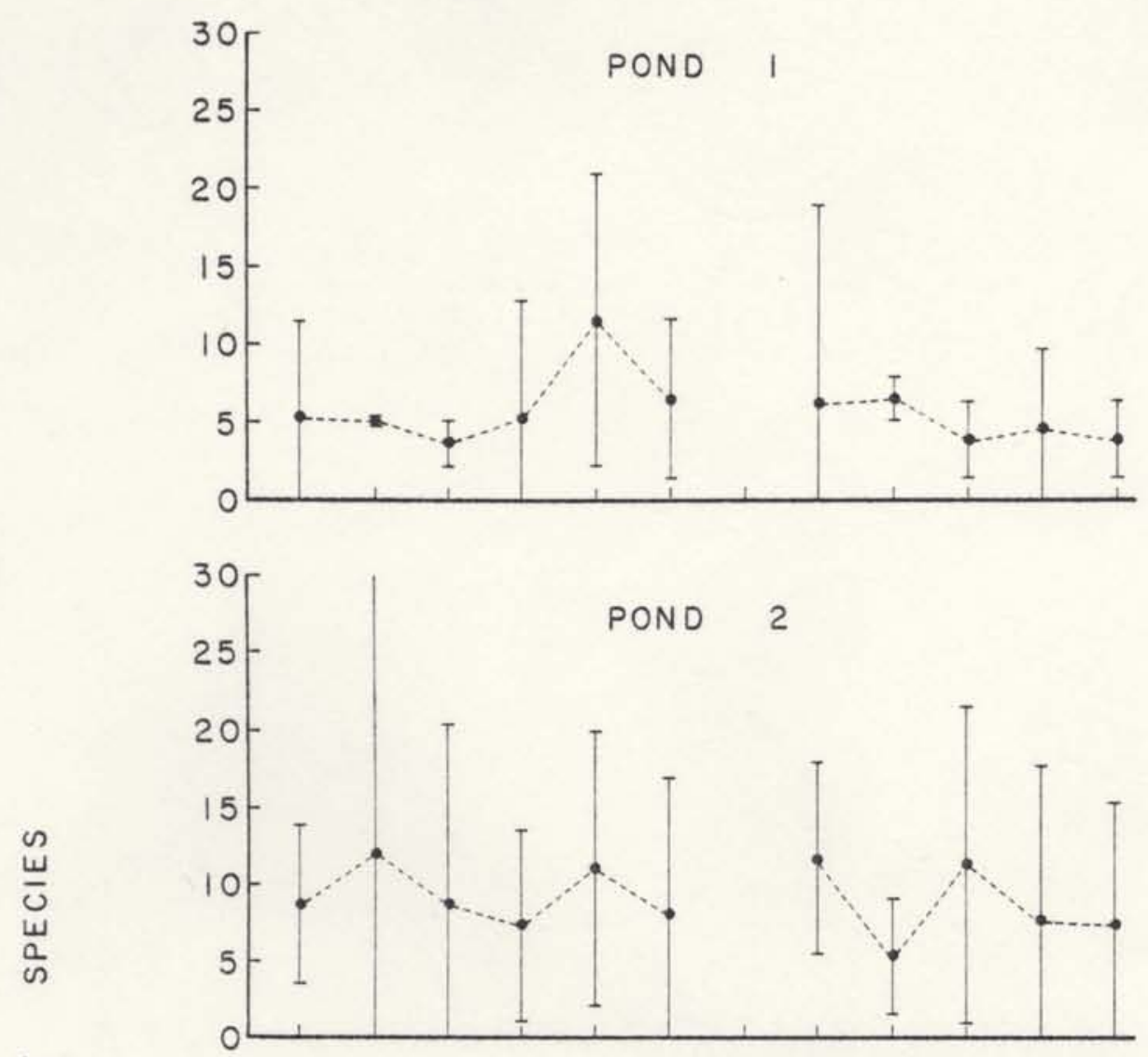

능
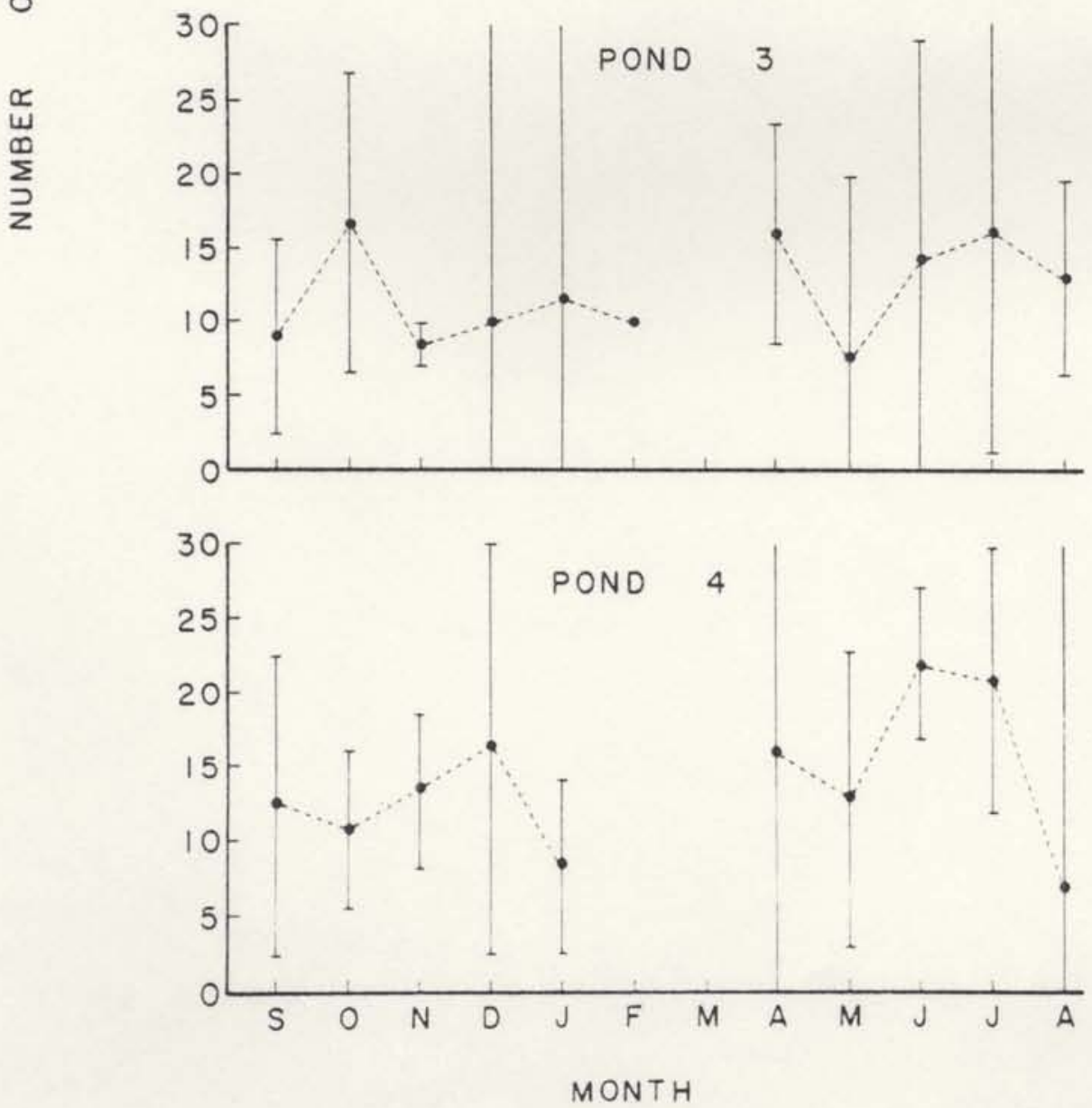
Fig. 11. Monthly means and $95 \%$ confidence intervals of the Shannon Index $(\bar{d})$ for the zooplankton in four FTU experimental ponds, September, 1975-August, 1976. 

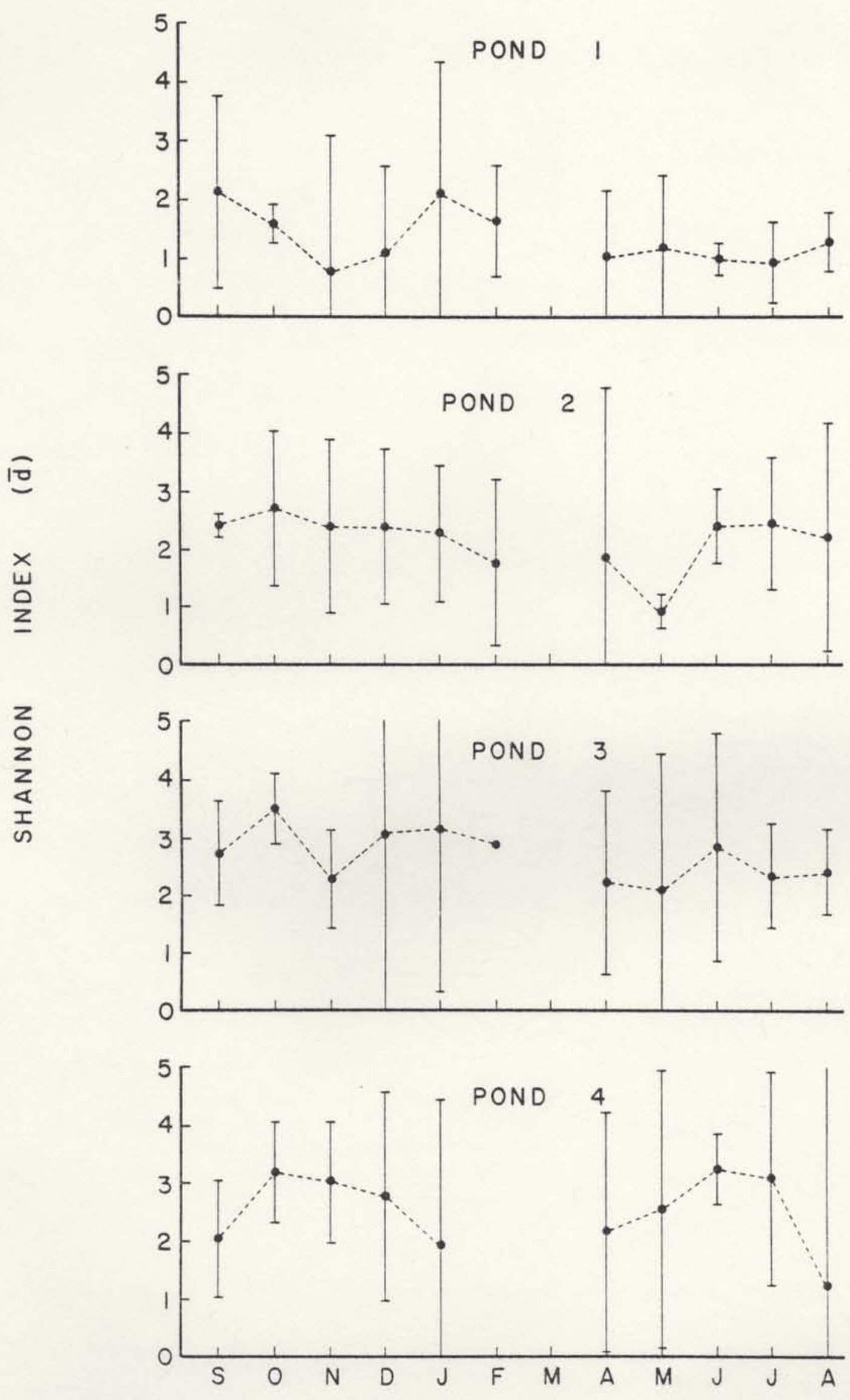

MONTH 
rotifers were most abundant and the number of species was high (Fig. 12). The Simpson Index values were less than 0.5 in Ponds 2,3 , and 4 , indicating a lack of species dominance.

Pond 1 had the highest annual mean value for redundancy $(0.42)$ and the lowest annual mean value for equitability $(0.58)$ of the ponds (Table 6). Redundancy values were greater than 0.5 throughout most of the year in that pond (Fig. 13). The annual mean redundancy values ranged between 0.22 and 0.35 in the ponds containing vegetation, with monthly values usually less than 0.25 . The annual mean equitability was more than 0.65 in those ponds. In general, the equitability values were highest during fall, 1975, and lowest during early spring, 1976 (Fig. 14). The range of these indices indicates a rather uniform distribution of individuals among the species in all ponds. Effect of Grass Carp on Zooplankton in Vegetated Ponds

The zooplankton in Pond 2 (low grass carp stocking rate), Pond 3 (high grass carp stocking rate), and Pond 4 (no grass carp) were similar during the eight months after the grass carp were stocked. Rotifers were most abundant during that period, with means of more than 50 individuals per liter (Table 7). Immature copepods were second in abundance in those ponds. The zooplankton groups were not statistically different between Ponds 2,3 , and 4 after the fish were stocked.

Significant differences were found between ponds for Lecane luna, Monostyla bulla, Lepadella ehrenbergii, Polyarthra vulgaris, and Synchaeta stylata numbers. It is doubtful, however, that the differences were caused by the grass carp. Grass carp longer than 
Fig. 12. Monthly means and $95 \%$ confidence intervals of the Simpson Index for the zooplankton in four FTU experimental ponds, September, 1975-August, 1976. 

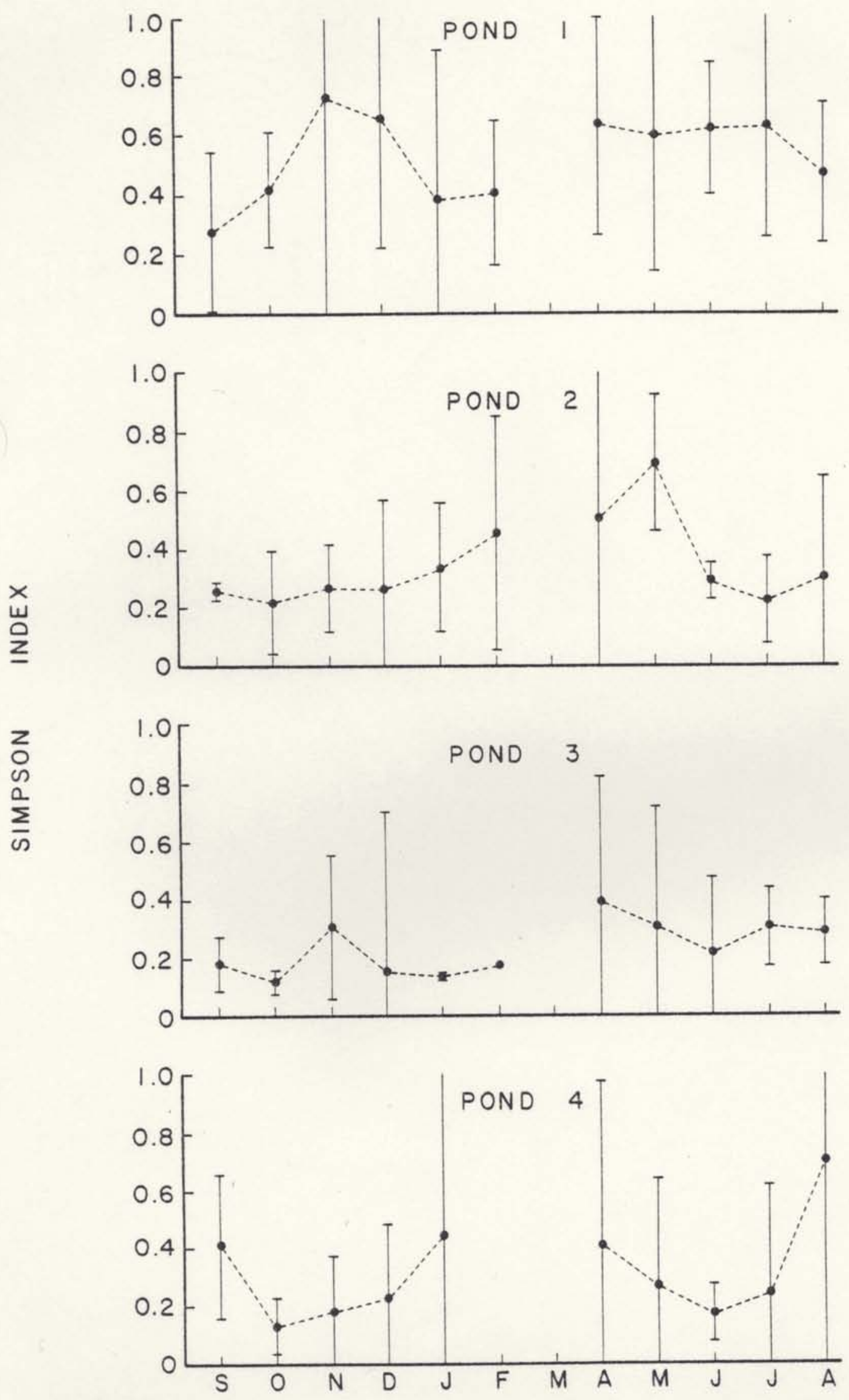
Fig. 13. Monthly means and $95 \%$ confidence intervals of the Redundancy Index for the zooplankton in four FTU experimental ponds, September, 1975-August, 1976. 

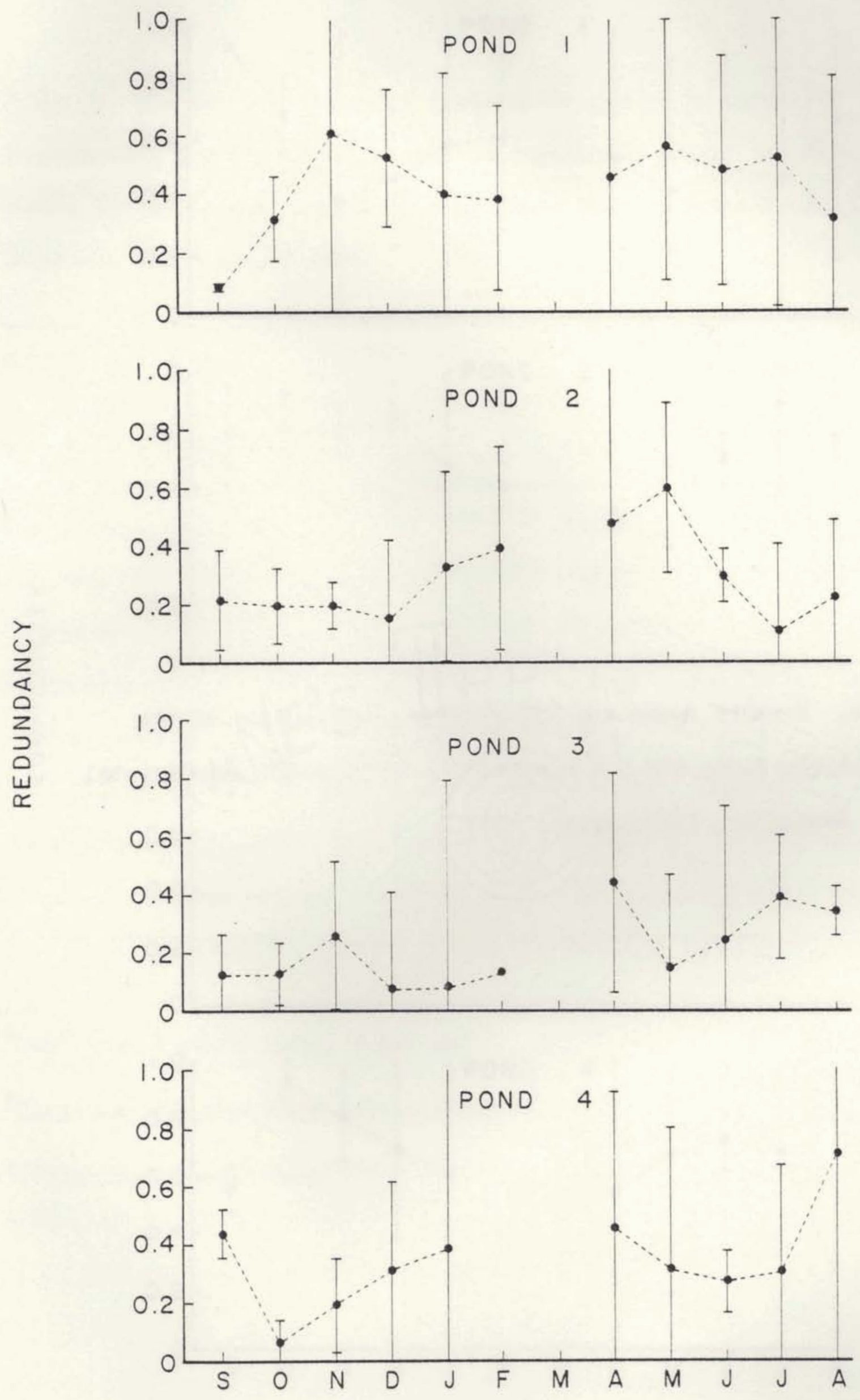

MONTH 
Fig. 14. Monthly means and $95 \%$ confidence intervals of the Equitability Index for the zooplankton in four FTU experimental ponds, September, 1975-August, 1976. 


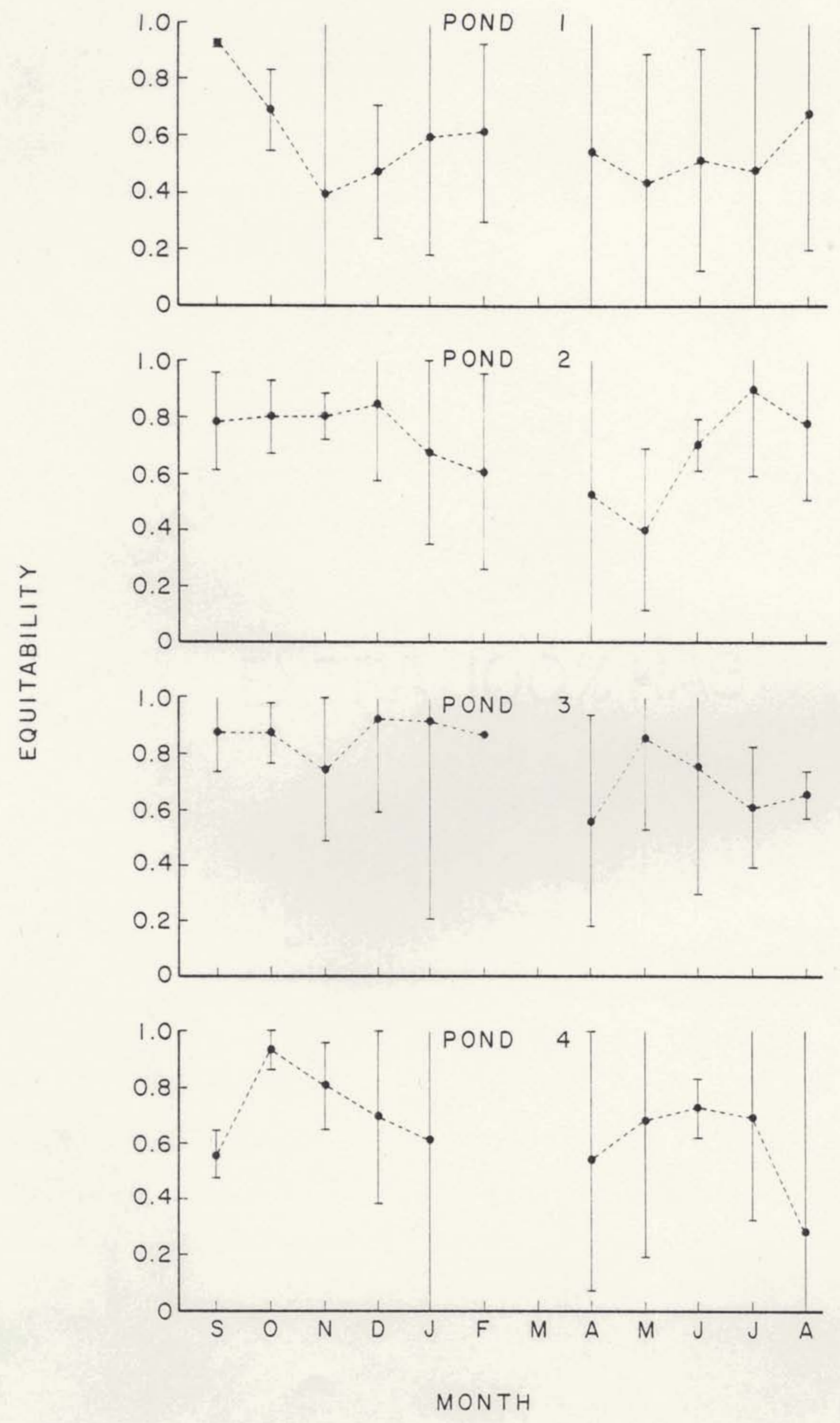


Table 7. The mean abundance of zooplankton groups in three FTU experimental ponds containing aquatic vegetation during the eight months following the introduction of grass carp in Ponds 2 and 3 , December, 1975-August, 1976.

\begin{tabular}{lccc}
\hline & \multicolumn{3}{c}{ Individuals per Iiter } \\
\cline { 2 - 4 } Zooplankton Group & Pond $2^{\mathrm{a}}$ & Pond $3^{\mathrm{b}}$ & Pond $4^{\mathrm{c}}$ \\
\hline Total Zooplankton & 118.4 & 153.2 & 150.6 \\
Rotifera & 51.0 & 93.7 & 119.9 \\
Cladocera & 13.0 & 7.9 & 5.1 \\
Adult Copepoda & 13.9 & 14.5 & 3.9 \\
Cyclopoida & 12.0 & 14.4 & 3.8 \\
Calanoida & 0.1 & ---- & ---- \\
Harpactacoida & 1.8 & 0.1 & 0.1 \\
Immature Copepoda & 40.5 & 37.1 & 21.7 \\
\hline
\end{tabular}

${ }^{a_{C}}$ Contained 9 grass carp ( 65 per ha)

${ }^{b}$ Contained 85 grass carp (611 per ha)

${ }^{C}$ Contained no grass carp 
$30 \mathrm{~mm}$ are primarily herbivorous and usually consume negligable amounts of animal food (Hickling, 1966). Grass carp fingerlings, up to $12 \mathrm{~cm}$ in length, have been observed to feed heavily upon Daphnia and other zooplankters (Stevenson, 1965), as have $22.9 \mathrm{~cm}$ (9 inch) long grass carp (Cross, 1969). In most pond situations, however, adult grass carp probably feed exclusively upon vegetation (Stevenson, 1965; Greenfield, 1973).

Species diversity and species dominance indices were not statistically different between the pond with high grass carp numbers (Pond 3) and the pond with no grass carp (Pond 4). However, the number of species was found to be significantly different in Pond 2 (low grass carp stocking rate; 9 species) when compared to Ponds 3 and 4 (12 and

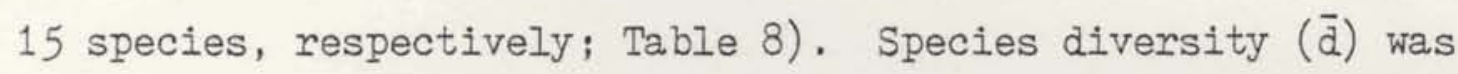
significantly lower in Pond 2 (2.04) than in Pond 3 (2.62) but was not statistically different from Pond $4(2.41)$. The grass carp probably did not influence the number of zooplankton species or their diversity in Pond 2; the species diversity ( $\bar{d})$ between June and August, 1976, was similar to that prior to grass carp stocking (see Fig. 11). The number of species was relatively low and constant throughout the study in Pond 2 (see Fig. 10). Beach et al. (1976) did not observe any change in the species or dominance diversity of zooplankton during a three-year study following the introduction of grass carp in four Florida ponds (Suwanee Pond, Madison Pond, Pasco Pond, and Broward Pond).

Zooplankton may be affected indirectly by adult grass carp. Fecal material produced by the fish may cause an increase in the nutrient content of water (Opuszynski, 1972; Stroganov, 1963). Stanley (1974) 
Table 8. Mean values for zooplankton species diversity indices in three FTU experimental ponds containing aquatic vegetation during the eight months following the introduction of grass carp in Ponds 2 and 3 , December, 1975-August, 1976.

\begin{tabular}{llll}
\hline & \multicolumn{3}{c}{ Individuals per liter } \\
\cline { 2 - 4 } Species Diversity Index & Pond $2^{\mathrm{a}}$ & Pond $3^{\mathrm{b}}$ & Pond $4^{\mathrm{c}}$ \\
\hline Number of Species & 9 & 12 & 15 \\
Shannon Index ( $\overline{\mathrm{d}})$ & 2.04 & 2.62 & 2.41 \\
Simpson Index (SI) & 0.38 & 0.25 & 0.35 \\
Redundancy (R) & 0.32 & 0.23 & 0.39 \\
Equitability (E) & 0.68 & 0.77 & 0.61 \\
\hline
\end{tabular}

${ }^{a}$ Contained 9 grass carp (65 per ha)

bontained 85 grass carp ( 611 per ha)

${ }^{C}$ Contained no grass carp 
has shown that, when fed mature elodea (Egeria densa), grass carp appeared to recycle nitrogen and phosphorus, thus making these nutrients available for phytoplankton, macrophytes, and microorganisms (Sutton and Blackburn, 1972; Stanley, 1974). Terrell (1975) and Rottmann (1977), however, suggest that these nutrients probably would not become available to the phytoplankton. Terrell (1976) found that the standing crop of zoo- and phytoplankton in eight Georgia ponds was lower in ponds stocked with grass carp than in those without the fish. He believed that the removal of macrophytes by the grass carp reduced the cycling of nutrients from the sediments to the plankton.

Orthophosphate, nitrite nitrogen, and nitrate nitrogen concentrations did not change in the ponds during this study. The nutrient content after grass carp were stocked was not statistically different between ponds (Table 9). Also, pelagic chlorophyll concentrations, periphytic algae production, total phytoplankton, filamentous phytoplankton, and single-cell phytoplankton counts were not found to be statistically different between the ponds after grass carp were stocked. Colonial phytoplankton was statistically more abundant in Pond 4 (911 individuals per $\mathrm{ml}$ ) than in Pond 2 (304 individuals per $\mathrm{ml}$ ), but was not significantly different between Pond 3 (high grass carp stocking rate) and Pond 4 (no grass carp). Avault et al. (1968) found that a grass carp stocking rate of 1,693 per hectare ( 23 to $30 \mathrm{~cm}$ lengths) in plastic pools and 495 fish per hectare (25 cm lengths) in concrete pools resulted in the development of a dark organic stain in the water. This did not occur in the ponds containing grass carp during this study; no significant 
Table 9. Means of physicochemical and biological parameters in Ponds 2,3 , and 4 during the eight months following the introduction of grass carp in Ponds 2 and 3, December, 1975-August, 1976.

Parameter

Temperature Top Meter $\left({ }^{\circ} \mathrm{C}\right)$

Temperature Bottom Meter $\left({ }^{\circ} \mathrm{C}\right)$

Iight Extinction Coefficient (k)

Secchi Visibility $(\mathrm{cm})$

Color (Pt-Co Units)

Turbidity (FTU)

Dissolved Oxygen (ppm)

$\mathrm{pH}$

Carbonate Alkalinity ( $p$ pm $\mathrm{CaCO}_{3}$ )

Bicarbonate Alkalinity ( $\mathrm{ppm} \mathrm{CaCO}_{3}$ )

Total Alkalinity (ppm $\mathrm{CaCO}_{3}$ )

Specific Conductivity (micromhos/cm @ 25 $\mathrm{C}$ )

Orthophosphate (ppm)

Nitrite Nitrogen (ppm)

Nitrate Nitrogen (ppm)

Pelagic Algae Chlorophyll (ppb)

Periphytic Algae Chlorophyll Production

$$
\left(\mathrm{mg} / \mathrm{m}^{2} * \text { day }\right)
$$

Total Phytoplankton (no. per ml)

Filamentous Phytoplankton (no. per ml)
Pond 2 Pond 3 Pond 4

$23.0 \quad 23.0 \quad 22.9$

$\begin{array}{lll}22.9 & 22.6 & 22.5\end{array}$

$\begin{array}{lll}2.06 & 1.92 & 2.07\end{array}$

$96.4 \quad 103.4 \quad 103.4$

$\begin{array}{lll}13.1 & 13.0 & 14.0\end{array}$

$\begin{array}{lll}3.3 & 4.4 & 3.5\end{array}$

$\begin{array}{lll}8.71 & 8.35 \quad 8.06\end{array}$

$\begin{array}{lll}7.9 & 7.9 & 8.0\end{array}$

$\begin{array}{lll}0.0 & 0.0 & 0.3\end{array}$

$\begin{array}{lll}140.7 & 136.2 & 143.5\end{array}$

$\begin{array}{lll}140.7 & 136.2 & 143.8\end{array}$

$\begin{array}{lll}274.1 & 264.1 & 273.9\end{array}$

$\begin{array}{ccc}0.023 & 0.013 & 0.010 \\ 0.011 & 0.011 & 0.013 \\ 0.054 & 0.050 & 0.055 \\ 17.5 & 13.0 & 21.4\end{array}$

2.11 .8

1.? 
Table 9, continued. Physicochemical and biological means during the eight months after grass carp stocking.

Pond 2 Pond 3 Pond 4

Colonial Phytoplankton (no. per ml)

$304 \quad 398 \quad 911$

Single-cell Phytoplanikton (no. per ml)

$1586 \quad 4034$

2138 
differences existed between Ponds 2, 3, and 4 for color and turbidity. of the remaining physical, chemical, and biological parameters which were measured, none was significantly different between Ponds 2, 3, and 4 after grass carp were stocked. Sutton (1972) also found that grass carp had little affect upon the water quality in ponds stocked with the fish.

Effect of Aquatic Vegetation on the Zooplankton

To determine the effect of aquatic vegetation, the zooplankton were compared between Pond 1 and Pond 4. Pond 1 was limnetic in nature, containing no submergent or emergent vegetation and only sparse growths of vegetation around the shore. In contrast, Pond 4 was primarily littoral, containing vegetation throughout.

Pond 1 contained a mean of four rotifer, one cladoceran, and two copepod species (Appendix 2). These values are similar to the number of species of these taxa typically found in the open water zone of lakes (Pennak, 1957). Pond 4 contained a mean of 11 rotifer, 2 cladoceran, and 1 copepod species. The number of cladoceran and copepod species in that pond is slightly less than is typically found in the weed zone of lakes (Pennak, 1966; Straskraba, 1963, 1965a, 1965b, 1967; Smyly, 1952, 1958; Smimov, 1963; Klimowicz, 1964). The mean number of rotifer species in Pond 4 is similar to that reported for littoral environments by Pennak (1966) and compares favorably with data from Lake Thonotosassa, Florida (Cowell et al., 1975). The total number of species and species diversity $(\bar{d})$ was significantly higher in Pond 4, while the Simpson Index was significantly higher in Pond 1 (see Table 6). These differences may have been due to the lack of aquatic 
vegetation in Pond 1. Zooplankton species may have been introduced into Pond 4 with the vegetation. Additionally, fewer habitats may have existed for the zooplankton in Pond 1, thus limiting shelters and food availability for a diverse zooplankton assemblage (Pennak, 1957). The abundance of rotifers, cladocerans, and copepods is generally 10 to $50 \%$ greater in open water than littoral regions (Pennak, 1966). The abundance of total zooplankton, cladocerans, calanoid copepods, and harpactacoid copepods was not statistically different between Ponds 1 and 4 in this study. Total rotifers, Lecane Iuna, Trichocerca sp., and Synchaeta stylata were significantly more abundant in Pond 4 , while immature copepods, adult copepods, and cyclopoids (including Mesocyclops edax and Tropocyclops prasinus) were significantly more abundant in Pond 1 (see Tables 4 and 5). Cladocerans and copepods tend to avoid the littoral zone and exhibit a non-random horizontal distribution in the pelagic zone. Higher numbers of rotifers are generally found in the littoral region in association with submersed macrophytes (Edmondson, 1946; Wetzel, 1975). Species of Trichocerca are typically found in littoral regions (Pennak, 1966; Smirnov, 1963). Straskraba (1967) found Lecane luna exists primarily in the littoral zone, although it also may be found in open water (Pennak, 1966). Synchaeta and Tropocyclops prasinus appear to be common in both vegetation and open water (Pennak, 1966; Smirnov, 1963; Straskraba, 1967; Armitage and Smith, 1968; Patalas, 1971, 1975).

Physicochemical parameters probably were not responsible for the differences in the zooplankton between Ponds 1 and 4 . The annual means for these parameters are presented in Table 10. Color and turbidity 
Table 10. Annual means of physicochemical and biological parameters in Ponds 1 and 4, September, 1975-August, 1976.

\begin{tabular}{|c|c|c|}
\hline Parameter & Pond 1 & Pond 4 \\
\hline Temperature Top Meter $\left({ }^{\circ} \mathrm{C}\right)$ & 23.8 & 23.4 \\
\hline Temperature Bottom Meter $\left({ }^{\circ} \mathrm{C}\right)$ & 23.7 & 23.1 \\
\hline Light Extinction Coefficient (k) & 2.56 & 1.98 \\
\hline Secchi Visibility (cm) & 94.3 & 103.4 \\
\hline Color (Pt-Co Units) & 21.6 & 14.1 \\
\hline Turbidity (FTU) & 4.8 & 3.0 \\
\hline Dissolved Oxygen (ppm) & 8.03 & 8.46 \\
\hline $\mathrm{pH}$ & 7.9 & 8.0 \\
\hline Carbonate Alkalinity (ppm $\mathrm{CaCO}_{3}$ ) & 0.4 & 0.2 \\
\hline Bicarbonate Alkalinity ( $\mathrm{ppm} \mathrm{CaCO}_{3}$ ) & 147.7 & 142.9 \\
\hline Total Alkalinity $\left(\mathrm{ppm} \mathrm{CaCO}_{3}\right)$ & 148.1 & 143.1 \\
\hline 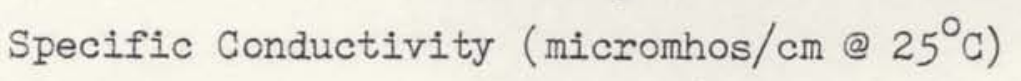 & 270.2 & 271.1 \\
\hline Orthophosphate (ppm) & 0.013 & 0.009 \\
\hline Nitrite Nitrogen (ppm) & 0.011 & 0.013 \\
\hline Nitrate Nitrogen (ppm) & 0.072 & 0.051 \\
\hline Pelagic Algae Chlorophyll (ppb) & 10.4 & 18.7 \\
\hline \multicolumn{3}{|l|}{ Periphytic Algae Chlorophyll Production } \\
\hline$\left(\mathrm{mg} / \mathrm{m}^{2} *\right.$ day $)$ & 2.0 & $1 \cdot 7$ \\
\hline Total Phytoplankton (no. per ml) & 11703 & 2668 \\
\hline Filamentous Phytoplankton (no. per ml) & 130 & 259 \\
\hline
\end{tabular}


Table 10, continued. Physicochemical and biological annual means in Ponds 1 and 4 .

Pond 1 Pond 4

Colonial Phytoplankton (no. per ml)

370

755

Single-cell Phytoplankton (no. per ml)

11238

1786 
concentrations were significantly higher in Pond 1 than in Pond 4. Turbidity was negatively correlated ( $r=-0.73 ; P<0.05 ; n=10)$ to total Cladocera in Pond 1 , and positively correlated ( $r=0.83 ; P<0.05 ; n=9)$ to Synchaeta stylata in Pond 4. Color was negatively correlated $(r=-0.78 ; P<0.05 ; n=9)$ to Monostyla tethis in Pond 4. Color and turbidity were not significantly correlated to the remaining species, zooplankton groups, or species diversity indices in Ponds 1 and 4 . The remaining physicochemical parameters were not significantly different between those ponds. Water chemistry may be important in affecting the zooplankton community structure in some cases (Hazelwood and Parker, 1961, 1963; Hutchinson, 1967), but usually has no affect on zooplankton in most freshwater environments (Hutchinson, 1957). Effect of Mosquitofish Populations on the Zooplankton

Mosquitofish (Gambusia affinis) were significantly less abundant in Pond 1 than in the other ponds (Table 11). Mosquitofish may have been responsible for the difference in zooplankton between Pond 1 and the other ponds. Selective predation by the mosquitofish may have reduced the copepod populations in Ponds 2, 3, and 4, resulting in the dominance of rotifers. The high abundances of copepods (adults and immatures) during summer, 1976, in Pond 1 may have been due to the virtual absence of mosquitofish during that period.

Fish are important in the regulation of the size and species composition of zooplankton communities (Cramer and Marzolf, 1970; Hillbricht-Ilkowska, 1964; Hrbacek, 1962; Hrbaceik et al., 1961; Novotna and Korinek, 1966; Straskraba, 1965b). The selective removal of zooplankton by planktivorous fish favors the survival of species that 
Table 11. The number of Gambusia affinis per trap in four FTU experimental ponds, September, 1975-August, 1976, presented as monthly and annual means.

\begin{tabular}{|c|c|c|c|c|}
\hline \multirow[b]{2}{*}{ Month } & \multicolumn{4}{|c|}{ Mean number of fish per trap } \\
\hline & Pond 1 & Pond 2 & Pond 3 & Pond 4 \\
\hline September, 1975 & 8 & 435 & 39 & 55 \\
\hline October & 43 & 253 & 146 & 90 \\
\hline November & 25 & 262 & 144 & 119 \\
\hline December & 66 & 198 & 119 & 82 \\
\hline January, 1976 & 25 & 235 & 207 & 207 \\
\hline February & 17 & 259 & 221 & 213 \\
\hline March & 123 & 347 & 96 & 285 \\
\hline April & 82 & 150 & 28 & 120 \\
\hline May & 30 & 75 & 20 & 83 \\
\hline June & 0 & 250 & 97 & 150 \\
\hline July & 0 & 330 & 157 & 201 \\
\hline August & 1 & 378 & 180 & 186 \\
\hline Annual Mean & 35 & 264 & 121 & 149 \\
\hline
\end{tabular}


are of small size and contain minimal amounts of visible pigmentation (Brooks, 1968; Brooks and Dodson, 1965; Reif and Tappa, 1966; Zaret, 1972a, 1972b, 1975; Zaret and Kerfoot, 1975). Under intense sizeselective predation, large zooplankters (cladocerans and calanoid copepods) are eliminated and small zooplankters (rotifers and small cladocerans) escape predation and become the dominants (Brooks, 1968; Hall et al., 1970). Cyclopoid copepods appear to be an intermediate food choice for most zooplanktivorous fish (Brooks, 1968). Hall et al. (1970) found rotifers to be three to six times more abundant in experimental ponds containing predacious fish than in ponds without fish.

The mosquitofish is known to prefer live food and is attracted to the movement of large prey more quickly than small prey (Hildebrand, 1921). Hurlbert et al. (1972) demonstrated that Gambusia affinis significantly reduced the abundance of cladocerans and copepod nauplii in artificial pools; rotifer populations were reduced after the larger prey were nearly eliminated. In the absence of mosquitofish, rotifer populations declined as cladoceran populations increased. Sampling Efficiency of the Shallow-Water Zooplankton Sampler

Hleven collections were taken with the shallow-water zooplankton sampler and a no. 20 zooplankton net. A total of 42 species were collected. Fifteen species were collected with the shallow-water sampler but not with the zooplankton net. Two species were collected only with the zooplankton net. Twenty-five species were common to both samplers, of which 19 were most abundant in the shallow-water sampler and 6 were most abundant in the zooplankton net. No significant 
differencés existed between the samplers for zooplankton groups or species. 


\section{SUMMARY}

1. Zooplankton were sampled monthly between September, 1975, and August, 1976, in four shallow experimental ponds ( 0.139 ha each) in central Florida. Samples were collected with a newly designed shallow-water zooplankton sampler. Pond 1 contained no aquatic vegetation. Ponds 2,3 , and 4 contained nine species of rooted aquatic macrophytes (four emergent, three floating-leaved, and two submergent species). Grass carp were stocked into Pond 2 ( 9 fish, 65 per ha) and Pond 3 (85 fish, 611 per ha). Mosquitofish (Gambusia affinis) were present in all ponds. Physicochemical and biological parameters were similar among the ponds.

2. Eighty-five zooplankton species were enumerated from the ponds. The lowest number of zooplankton species was found in Pond 1 (42). Twenty-eight percent of the species were common to all ponds. The Jaccard Index (species commonness between communities) was highest among ponds containing vegetation.

3. Zooplankton were most abundant in the pond lacking vegetation and were dominated by copepods (immatures and adults). Rotifers were dominant in the ponds with vegetation. Cyclopoids (particularly Tropocyclops prasinus) were the dominant copepods in all ponds. Cladocera were in low abundance.

4. The zooplankton in the ponds followed asynchronous population cycles. Zooplankton were most abundant during summer, 1976, in Ponds 
1 and 3, and during winter and early spring in Ponds 2 and 4 . In general, adult and immature copepod abundances paralleled total zooplankton in the pond lacking vegetation; rotifers paralleled total zooplankton throughout the study in the ponds containing vegetation.

5. The annual mean species diversity $(\bar{d})$ was lowest (1.34) and the Simpson Index highest $(0.53)$ in the pond lacking vegetation (Pond 1). Species diversity $(\bar{d})$ was highest $(2.68)$ in the pond containing vegetation and a high grass carp stocking rate (Pond 3 ). The annual mean Simpson Index values were less than 0.35 in the ponds with vegetation, indicating a lack of species dominance.

6. The abundance of zooplankton groups (Rotifera, Cladocera, and Copepoda) was not significantly different $(P<0.05)$ among the ponds containing vegetation and grass carp. No significant differences $(P<0.05)$ existed between Pond 3 (high grass carp stocking rate) and Pond 4 (no grass carp) for species diversity and species dominance. The number of species and species diversity $(\bar{d})$ was found to be significantly different $(P<0.05$ ) in Pond 2 (low grass carp stocking rate) when compared to Ponds 3 and 4; these differences were not believed to be due to the grass carp. Grass carp did not appear to affect the water quality of the ponds. In general, it was concluded that grass carp had little, if any, direct or indirect affect upon the zooplankton.

7. The lower number of species in Pond 1 was believed to be due to the lack of vegetation in that pond. The absence of vegetation at least partly appeared to be responsible for the lower abundances of rotifers and the higher abundances of copepods in Pond 1 than in the 
ponds containing vegetation. These differences may also have been due to predation by the mosquitofish (Gambusia affinis). This fish was significantly less abundant $(P<0.05)$ in Pond 1 than in the other ponds. This difference may have permitted larger zooplankters (e.g., copepods) to become dominant in Pond 1. Selective predation by the mosquitofish may have reduced the copepod populations in Ponds 2,3 , and 4 and resulted in the dominance of small zooplankters (e.g., rotifers).

8. A sampling efficiency determination of the shallow-water zooplankton sampler was made, compared to a no. 20 zooplankton net. No significant differences $(P<0.05)$ existed between the two samplers. 
Appendix 1. The monthly mean abundances and $95 \%$ confidence intervals for total rotifers, immature copepods, adult copepods, and cladocerans in four FTU experimental ponds, September, 1975-August, 1976. 
ROTIFERA
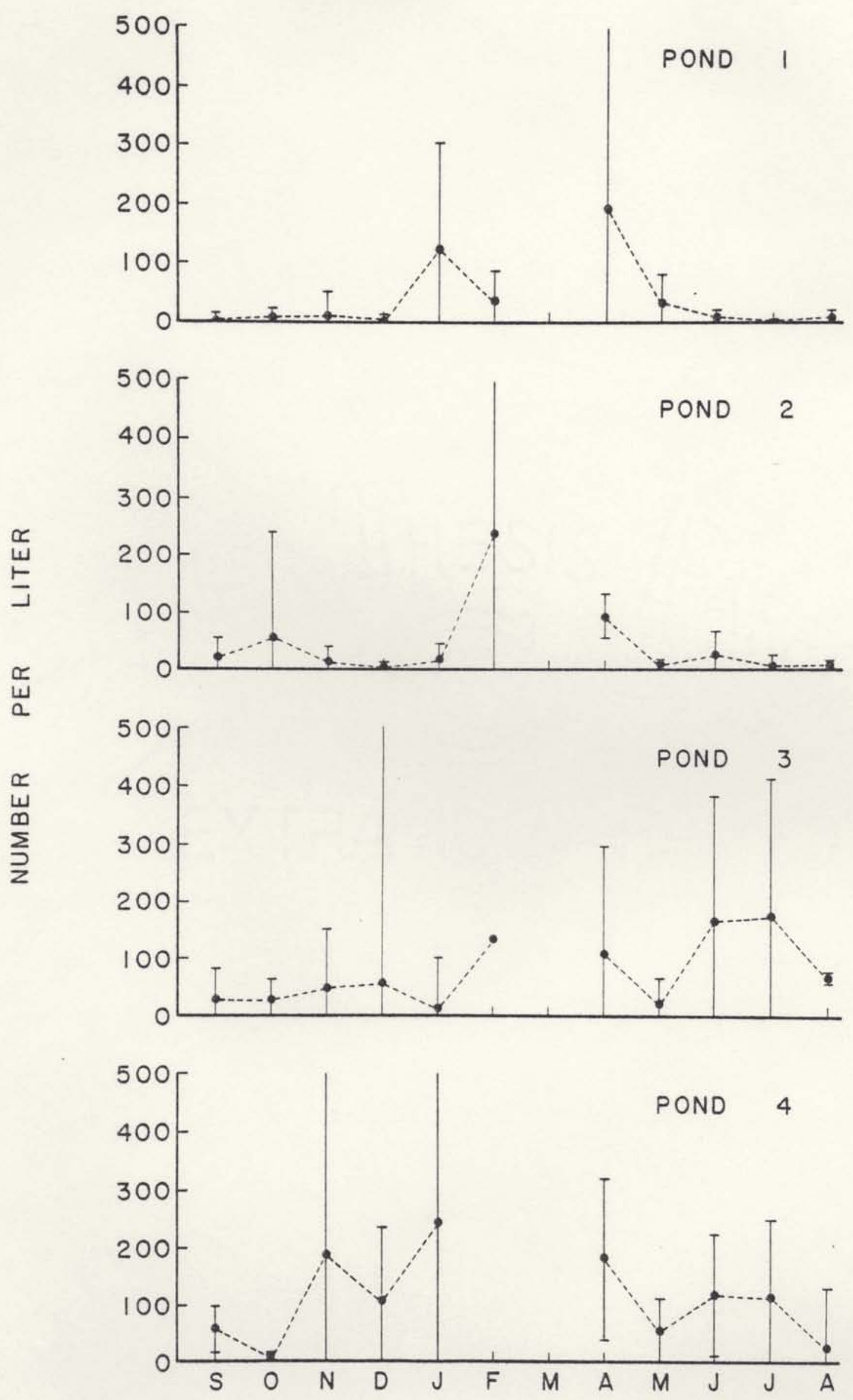

MONTH 
IMMATURE COPEIPODA
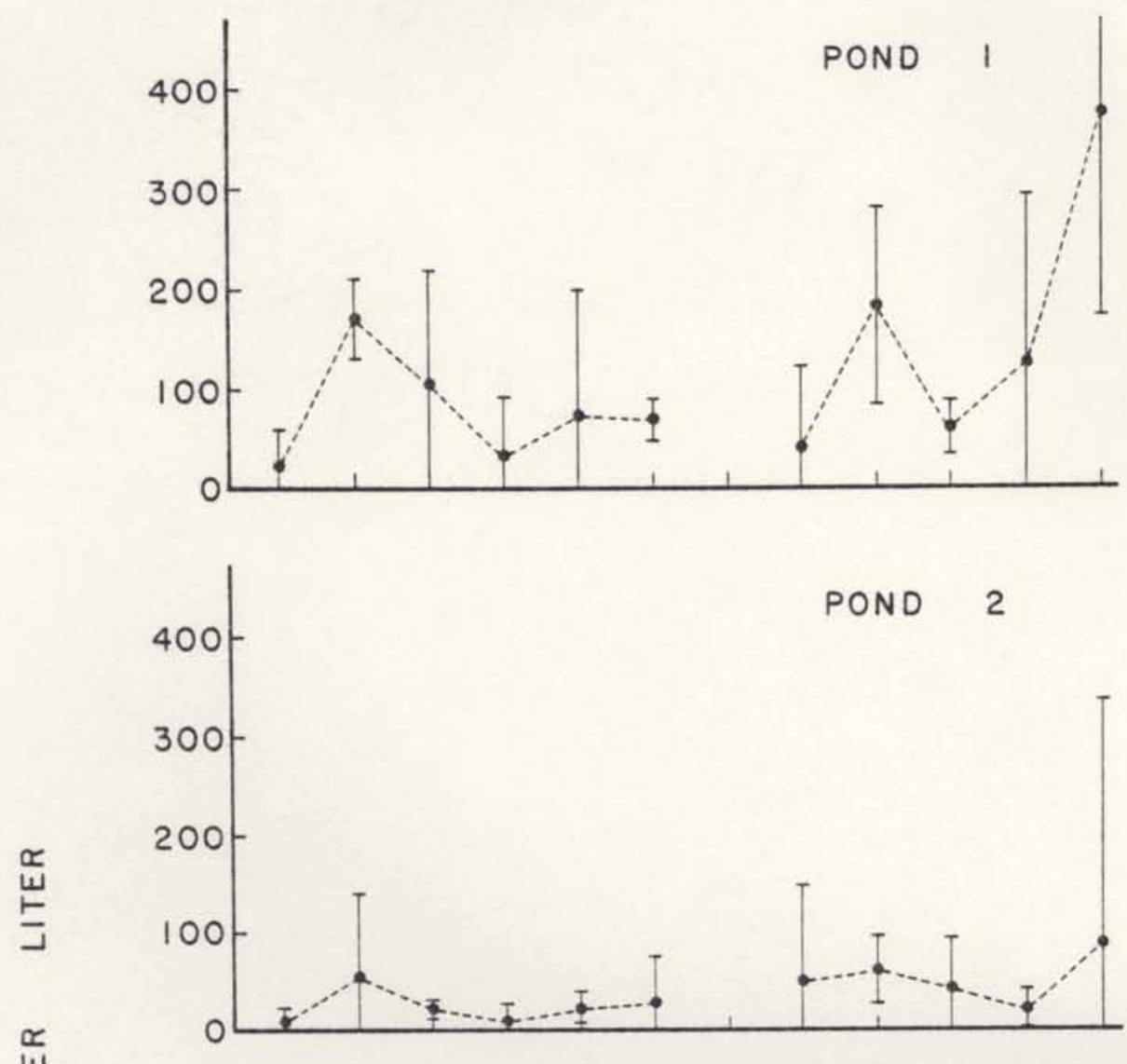

늠
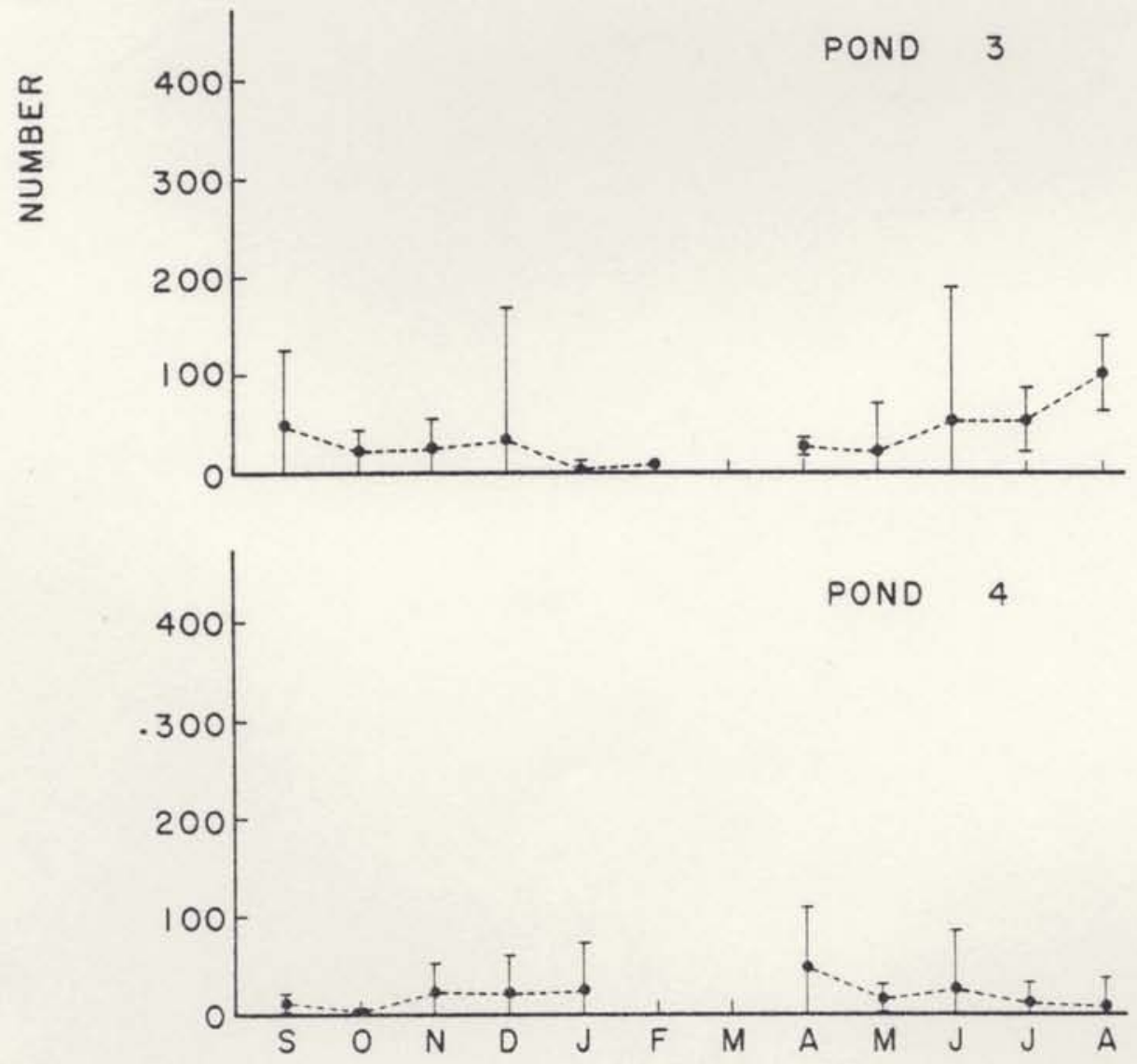

MONTH 


\section{ADULT COPEPODA}
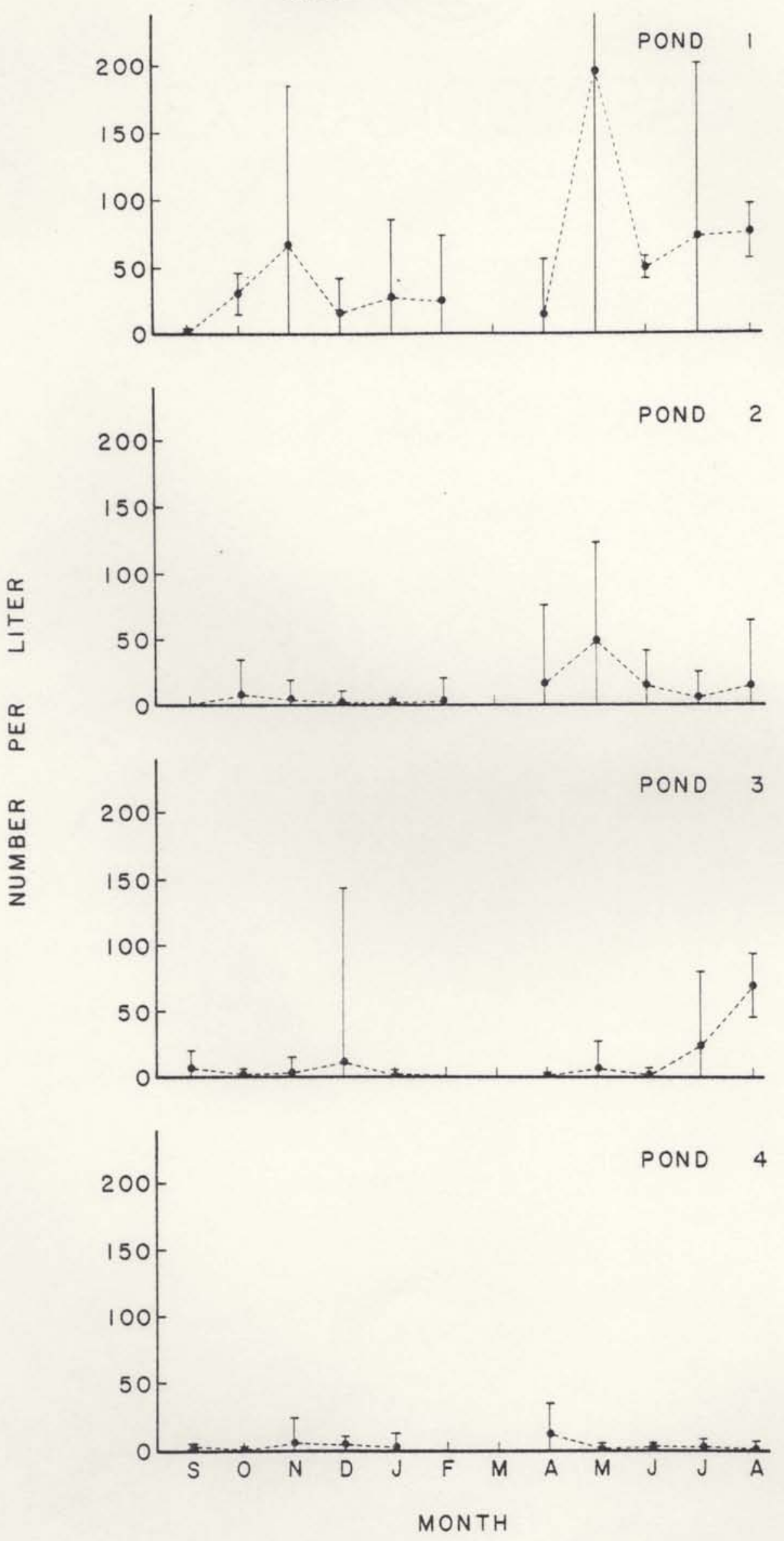
CLADOCERA

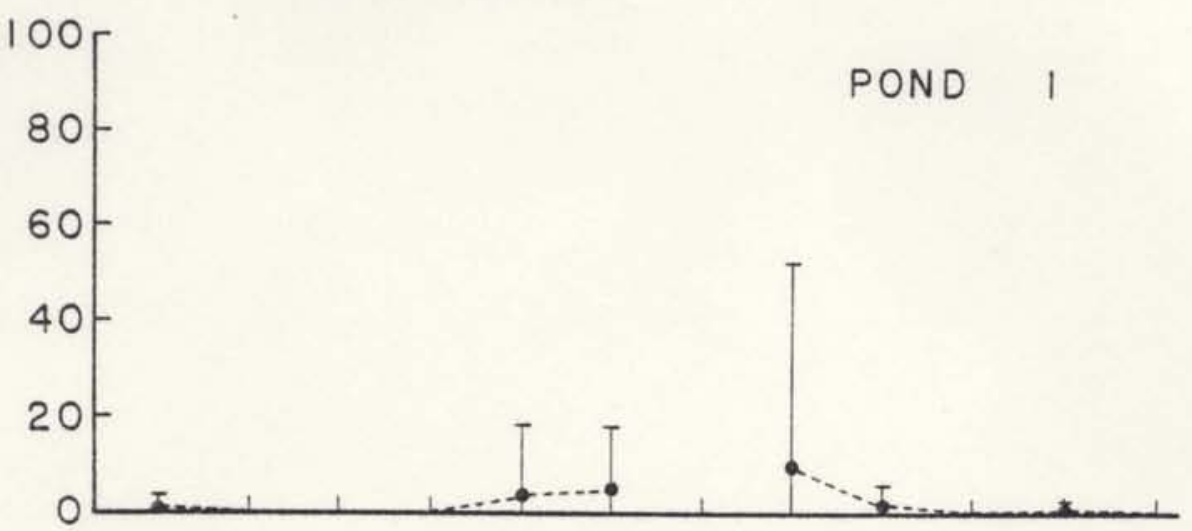

$\simeq$
$\amalg$
$\Xi$

$\frac{\sim}{u}$
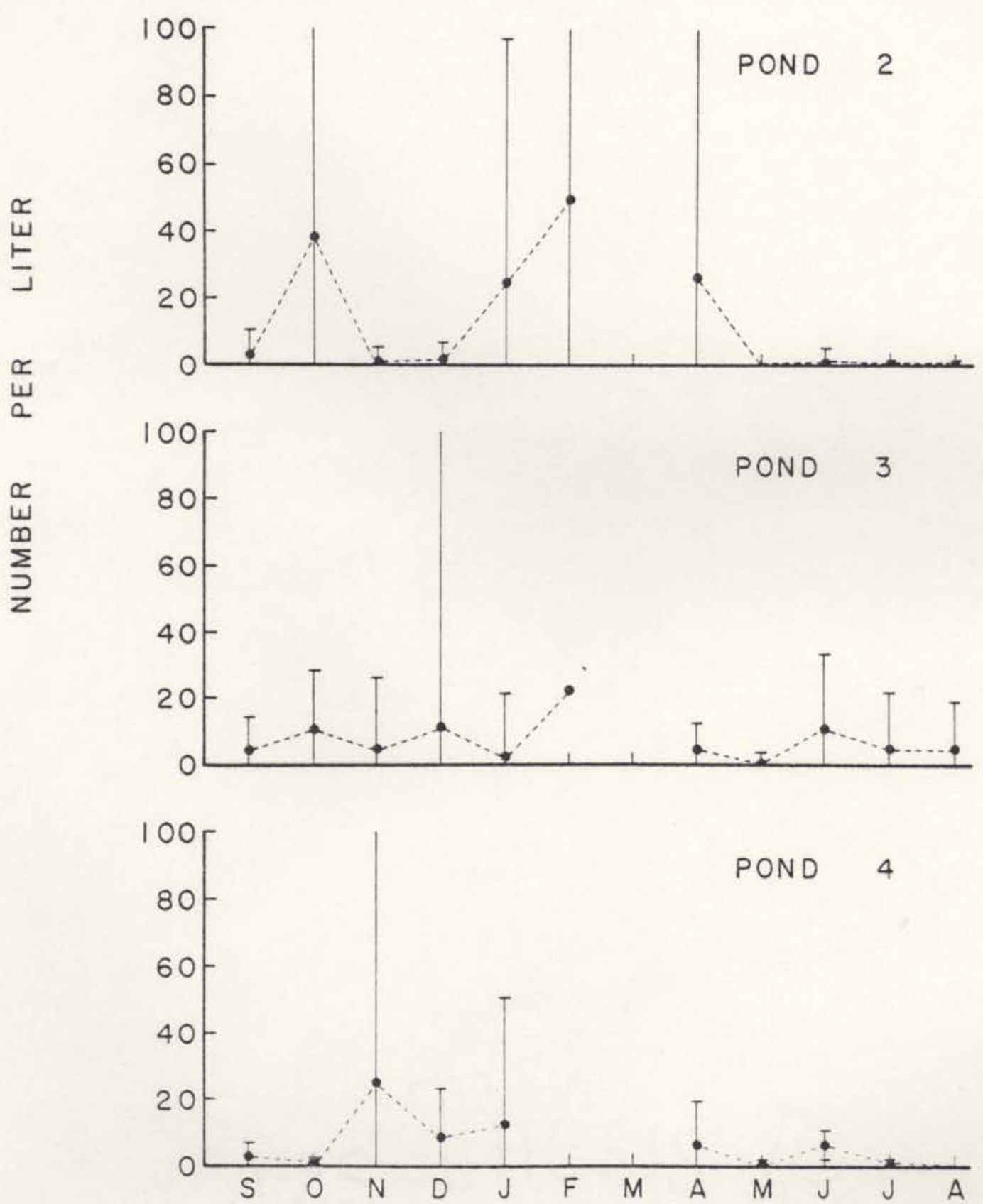
Appendix 2. Mean number of species of rotifers, cladocerans, and copepods present monthly in four FTU experimental ponds, September, 1975-August, 1976. 
Number of Species

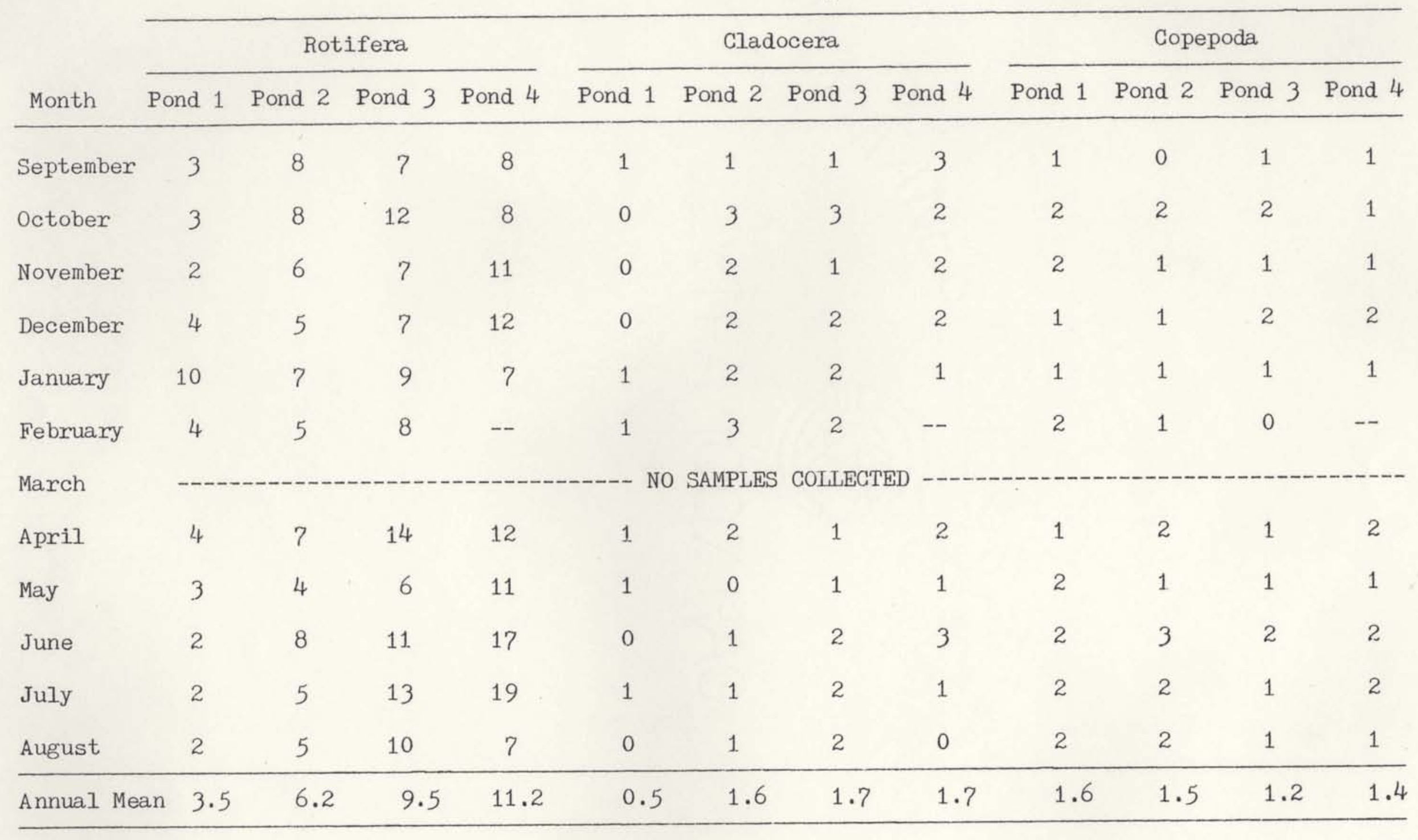




\section{REFEREINCES CITED}

Ackefors, H. 1971. A quantitative plankton sampler. Oikos 22:114118 .

Ahlstrom, E. H. 1934. Rotatoria of Florida. Trans. Am. Microsc. Soc. 53:251-266.

Amoros, G. 1973. Evolution des populations de Cladoceres et Copepodes dans trois etangs piscicoles de la Dombes (Changes in the populations of Cladocera and Copepoda in three fishponds of the Dombes). Ann. Iimnol. 9:135-155. (Abstr.; in French.)

Anderson, R. S. and Green, R. B. 1975. Zooplankton and phytoplankton studies in the Waterton Lakes, Alberta, Canada. Int. Ver. Theor. Angew. Limnol. Verh. 19:571-579.

Andersson, G., Berggren, H., and Hamrin, S. 1975. Lake Trummen restoration project III. Zooplankton, macrobenthos and fish. Int. Ver. Theor. Angew. Limnol. Verh. 19:1097-1106.

American Public Health Association. 1971. Standard methods for the examination of water and wastewater, 13th ed. Washington, D.C. $874 \mathrm{pp}$.

Armitage, K. B. and Smith, B. B. 1968. Population studies of pond zooplankton. Hydrobiologia $32: 384-416$.

Avault, J. W., Jr., Smitherman, R. 0., and Shell, E. W. 1968. Evaluation of eight species of fish for aquatic weed control. Pages 109-122 in Proceedings of the world symposium on warm-water pond fish culture, Rome. FAO Fish. Rept., 44. 5(VII/E-3).

Beach, M. I., Miley, W. W., II, Van Dyke, J. M., and Riley, D. M. 1976. The effect of the Chinese grass carp (Ctenopharyngodon idella (Val.)) on the ecology of four Florida lakes, and its use for aquatic weed control. Final Report, DNR-16, Bureau Aquatic Plant Res. Control, Fl. Dept. Nat. Resour., Tallahassee, Florida. $247 \mathrm{pp}$.

Borecky, G. W. 1956. Population density of the limnetic Cladocera of Pymatuning Reservoir. Ecology 37:719-727.

Brooks, J. I. 1957. The systematics of North American Daphnia. Mem. Conn. Acad. Arts Sci. 13:1-180. 
Brooks, J. I. 1959. Cladocera. Pages 587-656 in W. T. Edmondson, ed. Ward and Whipple's fresh-water biology, 2nd ed. John Wiley and Sons, Inc., New York.

Brooks, J. I. 1968. The effects of prey size selection by lake planktivores. Syst. Zool. 17:237-291.

Brooks, J. I. and Dodson, S. I. 1965. Predation, body size, and composition of plankton. Science 150:28-35.

Cowell, B. C., Dye, C. W., and Adams, R. C. 1975. A synoptic study of the limnology of Lake Thonotosassa, Florida Part I. Effects of primary treated sewage and citrus wastes. Hydrobiologia 46: $301-345$.

Cramer, J. D. and Marzolf, R. 1970. Selective predation on zooplankton by gizzard shad. Trans. Am. Fish. Soc. 99:320-332.

Cross, D. G. 1969. Aquatic weed control using grass carp. J. Fish. Biol. 1:27-30.

Daggett, R. F. and Davis, C. C. 1974. A seasonal quantitative study of the littoral Cladocera and Copepoda in a bog pond and an acid marsh in Newfoundland. Int. Rev. Gesamten Hydrobiol. 59:667-683.

Edmondson, W. T. 1946. Factors in the dynamics of rotifer populations. Ecol. Monogr. 16:357-372.

Edmondson, W. T. 1959. Rotifera. Pages 420-494 in W. T. Edmondson, ed. Ward and Whipple's fresh-water biology, $\overline{2 n d}$ ed. John Wiley and Sons, Inc., New York.

Environmental Protection Agency. 1974. Methods for chemical analysis of water and wastes. EPA-625/6-74-003. Washington, D.C. 298 pp.

Fox, J. I., Blancher, E. C., Kooijman, F. M., Conley, R. A., and Feerick, C. P. 1977. Biological baseline studies of the Lake Conway, Florida, system. Pages 123-145 in Proceedings, research planning conference on the aquatic plant control program, Misc. Paper A-77-3. U,S. Army Engineer Waterways Exper. Stat., Vicksburg, Miss.

Greenfield, D. W. 1973. An evaluation of the advisability of the release of the grass carp, Ctenopharyngodon idella, into the natural waters of the United States. Trans. IIl. State Acad. Sci. 66:47-53.

Hall, D. J., Cooper, W. E., and Werner, E. W. 1970. An experimental approach to the production dynamics and structure of freshwater animal communities. Limnol. Oceanogr. 15:837-928. 
Harring, H. K. and Myers, F. J. 1922. The rotifer fauna of Wisconsin. Trans. Wis. Acad. Sci. Arts Lett. 20:553-662.

Harring, H. K. and Myers, F. J. 1924. The rotifer fauna of Wisconsin.-II. A revision of the notommatid rotifers, exclusive of the Dicranophorinae. Trans. Wis. Acad. Sci. Arts Lett. $21: 415-549$.

Harring, H. K. and Myers, F. J. 1926. The rotifer fauna of Wisconsin.-III. A revision of the genera Lecane and Monostyla. Trans. Wis. Acad. Sci. Arts Lett. 22:315-423.

Harring, H. K. and Myers, F. J. 1928. The rotifer fauna of Wisconsin.-IV. The Dicranophorinae. Trans. Wis. Acad. Sci. Arts Lett. 23:667-808.

Hasler, A. D. and Jones, E. 1949. Demonstration of the antagonistic action of large aquatic plants on algae and rotifers. Ecology $30: 359-364$.

Hazelwood, D. H. and Parker, R. A. 1961. Population dynamics of some freshwater zooplankton. Ecology 42:266-274.

Hazelwood, D. H. and Parker, R. A. 1963. Population dynamics of some freshwater zooplankton II. The effect of lag. Ecology 44:207211.

Hickling, C. F. 1966. On the feeding process in the White Amur, Ctenopharyngodon idella. J. Zool. (Lond.) 148:408-419.

Hildebrand, S, F. 1921. Top minnows in relation to malaria control, with notes on their habits and distribution. U.S. Public Health Ser., Public Health Bull. 114:3-34.

Hillbricht-Ilkowska, A. 1964. The influence of the fish population on the biocenosis of a pond, using Rotifera fauna as an

illustration. Ekol. Pol. Ser. A 12:453-503.

Hrbacek, J. 1962. Species composition and the amount of zooplankton in relation to the fish stock. Rozpr. Cesk. Akad. Ved Rada Mat. Prir. Ved 72(10):1-116.

Hrbacek, J., Drorakova, M., Korinek, V., and Prochazkova, I. 1961. Demonstration of the effect of the fish stock on the species composition of zooplankton and the intensity of metabolism of the whole plankton association. Int. Ver. Theor. Angew. Limnol. Verh. $14: 192-195$.

Hurlbert, S. H., Zedler, J., and Fairbanks, D. 1972. Ecosystem alteration by mosquitofish (Gambusia affinis) predation. Science 175:639-641. 
Hutchinson, G. E. 1957. A treatise on limnology. Vol. I. Geography, physics, and chemistry. John Wiley and Sons, Inc., New York. $1015 \mathrm{pp}$.

Hutchinson, G. E. 1967. A treatise on limnology. Vol. II. Introduction to lake biology and the limnoplankton. John Wiley and Sons, Inc., New York. 1115 pp.

Icanberry, J. W. and Richardson, R. W. 1973. Quantitative sampling of live zooplankton with a filter-pump system. Iimnol. Oceanogr. $18: 333-335$.

Jaccard, P. 1908. Nouvelles rescherches sur la distribution florale. Bull. Soc. Vaudoise Sci. Nat. 44:223-270.

Kilgen, R. H. and Smitherman, R. 0. 1971. Food habits of the white amur stocked in ponds alone and in combination with other species. Prog. Fish.-Cult. 33:123-12?.

Klimowicz, H. 1964. Rotifers of "astatic waters" Part I. The littoral of Lake Kisajno. Pol. Arch. Hydrobiol. 12:279-305.

Krupaur, V. 1967. Food selection in two-year-old grass carp. Bull. Vyzk. Ustav Ryb., Vodnany CSSR 3:7-17. (In Czech; Abstr. in Agr. Res. Council Weed Res. Organ. Annot. Bibliogr. no. 31, 1971.)

Lind, 0. T. 1974. A handbook of common methods in limnology. The C. V. Mosby Co., St. Louis, Mo. $134 \mathrm{pp}$.

Nordlie, F. G. 1976. Plankton communities of three central Florida lakes. Hydrobiologia 48:65-78.

Novotna, M. and Korinek, V. 1966. Effect of the fishstock on the quantity and species composition of the plankton of two backwaters. Cesk. Akad. Ved Hydrobiol. Stud. 1:297-322.

O'Brien, W. J. and deNoyelles, F., Jr. 1974. Relationship between nutrient concentration, phytoplankton density, and zooplankton density in nutrient enriched experimental ponds. Hydrobiologia 44:105-125.

Opuszynski, K. 1968. Carp polyculture with plant-feeding fish: grass carp (Ctenopharyngodon idella Val.) and silver carp (Hypophthalmichthys molitrix Val.). Bull. Acad. Pol. Sci. Ser. sci. Biol. Cl. II, 16:677-681.

Patalas, K. 1971. Crustacean plankton communities in forty-five lakes in the Experimental Lakes Area, northwestern Ontario. J. Fish. Res. Board Can. 28:231-244. 
Patalas, K. 1972. Crustacean plankton and the eutrophication of St. Lawrence Great Iakes. J. Fish. Res. Board Can. 29:1451-1462.

Patalas, K. 1975. The crustacean plankton communities of fourteen North American great lakes. Int. Ver. Theor. Angew. Iimnol. Verh. 19:504-511.

Pennak, R. W. 1953. Fresh-water invertebrates of the United States. Ronald Press, New York. 769 pp.

Pennak, R. W. 1957. Species composition of limnetic zooplankton communities. Limnol. Oceanogr. 2:222-232.

Pennak, R. W. 1962. Quantitative zooplankton sampling in littoral vegetation areas. Limnol. Oceanogr. 7:487-489.

Pennak, R. W. 1966. Structure of zooplankton populations in the littoral macrophyte zone of some Colorado lakes. Trans. Am. Microsc. Soc. 85:329-349.

Pielou, E. C. 1966. The measurement of diversity in different types of biological collections. J. Theor. Biol. 13:131-144.

Quade, H. W. 1969. Cladoceran faunas associated with aquatic macrophytes in some lakes in northwestern Minnesota. Ecology $50: 170-179$.

Reid, G. K. and Blake, N. J. 1969. Diurnal zooplankton ecology in a phosphate pit lake. Q. J. Fla. Acad. Sci. 32:275-284.

Reid, G. K. and Squibb, S. D. 1971. Iimnological cycles in a phosphatic limestone mine lake. Q. J. Fla. Acad. Sci. 34:17-47.

Reif, C. B. and Tappa, D. W. 1966. Selective predation: smelt and cladocerans in Harveys Lake. Limnol. Oceanogr. 11:437-438.

Richard, D. 1973. Zooplankton studies in the Winter Park Lake Chain. Pages 85-128 in The Rollins College Biology Department, eds. Ecological studies of central Florida lakes Vol. VI. The Lake Virginia report, 1973 research program. Rollins College, Winter Park, Florida.

Richards, P. A. with Thompson, T. G. 1952. The estimation and characterization of plankton populations by pigment analysis. II. A spectrophotometric method for the estimation of plankton pigments. J. Mar. Res. 2:156-172.

Rottmann, R. 1977. Management of weedy lakes and ponds with grass carp. Fisheries 2:8-14. 
Schindler, D. W. and Noven, B. 1971. Vertical distribution and seasonal abundance of zooplankton in two shallow lakes of the Experimental Lakes Area, northwestern Ontario. J. Fish. Res. Board Can. 28:245-256.

Simpson, E. H. 1949. Measurement of diversity. Nature (Iond.) 163: 688.

Singh, S. B., Sukumaran, K. K., Pillai, K. K., and Chakrabarti, P. C. 1969. Observations on efficacy of grass carp, Ctenopharyngodon idella (Val.) in controlling and utilizing aquatic weeds in ponds in India. Proc. Indo-Pacific Fish. Coun. 12:220-235.

Smimov, N. N. 1963. On inshore Cladocera of the Volga Water Reservoirs. Hydrobiologia 21:166-176.

Smyly, W. J. P. 1952. The Entomostraca of the weeds of a moorland pond. J. Anim. Ecol. 21:1-11.

Smyly, W. J. P. 1958. Distribution and seasonal abundance of Entomostraca in moorland ponds near Windermere. Hydrobiologia $11: 59-72$.

Spodniewska, I., Hillbricht-Ilkowska, A., and Weglenska, T. 1973. Iong-term changes in the plankton of eutrophic Mikolajskie Iake as an effect of accelerated eutrophication. Bull. Acad. Pol. Sci. Ser. Sci. Biol. Cl. II, 21:215-221.

Stanley, J. G. 1974. Nitrogen and phosphorus balance of grass carp, Ctenopharyngodon idella, fed elodea, Egeria densa. Trans. Am. Fish. Soc. 103:587-592.

Steel, R. G. D. and Torrie, J. H. 1960. Principles and procedures in statistics. McGraw-Hill, New York. 481 pp.

Stevenson, J. H. 1965. Observations on grass carp in Arkansas. Prog. Fish.-Cult. 27:203-206.

Straskraba, M. 1963. Share of the littoral region in the productivity of two fishponds in southern Bohemia. Rozpr. Cesk. Akad. Ved Rada Mat. Prir. Ved 73(13):1-64.

Straskraba, M. 1965a. Contributions to the productivity of the littoral region of pools and ponds I. Quantitative study of the littoral zooplankton of the rich vegetation of the backwater Labicko. Hydrobiologia 26:421-443.

Straskraba, M. 1965b. The effect of fish on the number of invertebrates in ponds and streams. Mitt. Int. Ver. Theor. Angew. Limnol. 13:106-12? . 
Straskraba, M. 1967. Quantitative study on the littoral zooplankton of the Poltruba Backwater with an attempt to disclose the effect on fish. Rozpr. Cesk. Akad. Ved Rada Mat. Prir. Ved 77(11):7-34.

Stroganov, N. S. 1963. The food selectivity of the Amur fishes. Pages 181-191 in Symposium: problems of the fisheries exploitation of plant-eating fishes in the water bodies of the U.S.S.R. Tr. Akad. Nauk. Turkm. SSR. (Trans. from Russian; From Ref. Zh. Biol., 1964, no. 3T32.)

Sutton, D. I. 1972. Progress report to the Florida Department of Natural Resources on the project: control of aquatic plant growth in earthen ponds by the white amur. Period covering: July, 1971 to March, 1972. Unpublished.

Sutton, D. I. and Blackburn, R. D. 1972. Feasibility of the amur (Ctenopharyngodon idella Val.) as a biocontrol of aquatic weeds, Appendix D. Pages 1-80 in E. O. Gongstad, J. J. Raynes, and R. M. Burress, eds. Technical report on herbivorous fish for aquatic plant control. Dept. of the Army, Off. Chief Engin., Washington, D.C.

Terrell, T. T. 1975. The impact of macrophyte control by the white amur (Ctenopharyngodon idella). Int. Ver. Theor. Angew. Limnol. Verh. 19:2510-2514.

Terrell, T. T. 1976. Environmental impact of the white amur (Ctenopharyngodon idella Val.) on some Georgia ponds. Ph.D. Thesis. Univ. Georgia, Athens, Georgia. 42 pp.

van Heusden, G. P. H. 1972. Estimation of the biomass of plankton. Hydrobiologia 39:165-208.

Voigt, M. 1956. Rotatoria. Die Radertiere Mitteleuropas. Gebruder Borntraeger, Berlin. 508 pp.

Wetzel, R, G. 1975. Limnology. W. B. Saunders Co., Philadelphia. $743 \mathrm{pp}$.

Wilhm, J. I. and Dormis, T. C. 1968. Biological parameters for water quality. BioScience 18:477-481.

Wilson, M. S. 1959. Calanoida. Pages 738-794 in W. T. Edmondson, ed. Ward and Whipple's fresh-water biology, 2nd ed. John Wiley and Sons, Inc., New York.

Wilson, M. S. and Yeatman, H. C. 1959. Harpactacoida. Pages 815-861 in W. T. Edmondson, ed. Ward and Whipple's fresh-water biology, $\overline{2 n d}$ ed. John Wiley and Sons, Inc., New York. 
Yeatman, H. C. 1959. Cyclopoida. Pages 795-815 in W. T. Edmondson, ed. Ward and Whipple's fresh-water biology, 2nd ed. John Wiley and Sons, Inc., New York.

Zaret, T. M. 1972a. Predators, invisible prey, and the nature of polymorphism in the Cladocera (Class Crustacea). Limnol. Oceanogr. 17:171-184.

Zaret, T. M. 1972b. Predator-prey interaction in a tropical lacustrine ecosystem. Ecology 53:248-257.

Zaret, T. M. 1975. Strategies for existence of zooplankton prey in homogeneous environments. Int. Ver. Theor. Angew. Limnol. Verh. 19:1484-1489.

Zaret, T. M. and Kerfoot, W. C. 1975. Fish predation on Bosmina longirostris: body size selection versus visibility selection. Ecology 56:232-237. 